DOI: 10.1002/adsc.201((will be filled in by the editorial staff $))$

\title{
Iron-based imidazolium salts as versatile catalysts for the synthesis of quinolines and 2- and 4-allylanilines by allylic substitution of alcohols.
}

\author{
Paz Trillo ${ }^{a *}$ and Isidro M. Pastor ${ }^{a *}$ \\ a Department of Organic Chemistry, Faculty of Science and Instituto de Síntesis Orgánica (ISO), University of Alicante, \\ Apdo. 99, 03080, Alicante, Spain \\ Fax: (+34) 965903549 \\ e-mails: paz.trillo@ua.es; ipastor@ua.es
}

Received:((will be filled in by the editorial staff))

Supporting Information for this article is available on the WWW under http://dx.doi.org/10.1002/adsc.201\#\#\#\#\#\#.((Please delete if not appropriate))

\begin{abstract}
Readily available iron(III) based imidazolium salts have proven to be very versatile catalysts for the allylic substitution reaction of alcohols with anilines, allowing the synthesis of quinolines, 2-allylanilines and 4-allylanilines just by modulating the reaction conditions. Noteworthy, the formation of quinoline derivatives proceeds by orthoallylation of the corresponding aniline and subsequent oxidative cyclization mediated by atmospheric oxygen.
\end{abstract}

The reaction using anilines as nucleophiles is selective to the $\mathrm{C}$-alkylation versus the $\mathrm{N}$-alkylation, under any reaction conditions studied.

Keywords: Iron(III) catalyst; Imidazolium salt; Allylic alcohol; C-alkylation; Quinoline

\section{Introduction}

The search and development of new strategies towards the design of green and sustainable transformations, which minimize waste production and avoid the use of toxic or expensive reagents or catalysts, is a current challenge for the organic chemical community. Indeed, sustainability is the main goal of green chemistry. ${ }^{[1]}$ In this sense, and in the particular case of allylic substitution reactions, the replacement of the most commonly used 'big' leaving groups (e.g. carbonates and acetates) with the direct use of a hydroxy group, is an attractive strategy from both a practical and environmental point of view, as water would be the only by-product. However, this approach has two main limitations, the poor ability of the hydroxy group as leaving-group and the formation of stoichiometric amounts of water, which could deactivate the catalyst.

Remarkably efforts have been made in the last years in the design of new catalytic systems which can carry out this reaction and overcome these limitations. $^{[2]}$ Recently, iron-based catalysts have emerged as an interesting alternative to other more expensive and toxic metallic catalysts. ${ }^{[3]}$ These ironcatalyts cover a good range of transformations, but there is still room for improvement and new discoveries in the area. Being aware of that, our group, interested in the development and study of efficient, cost-effective and environmentally friendly processes, envisioned the design of different iron(III)- based Lewis acidic ionic liquids (IBLAILs) (Figure 1). This type of metal-ion-containing ionic liquids has received attention in the last years. ${ }^{[4]}$ Indeed, imidazolium-based ionic liquids (ILs) containing anionic iron(III) has been reported for extractive desulfurization of fuel oils, ${ }^{[5]}$ being also effective in the extraction coupled with oxidative desulfurization. ${ }^{[6]} \quad$ Moreover, the 1-butyl-3methylimidazolium tetrachloro-ferrate has been employed as efficient catalyst in the coupling between aryl Grignard reagents and alkyl halides ${ }^{[7]}$ and in the dimerization of norbornadiene,${ }^{[8]}$ being possible the recyclability of the catalyst. The threecomponent reaction between an aldehyde, a Bketoester and urea (Biginelli reaction) has been performed successfully in the presence of an ironcontaining ionic liquid as solvent and catalyst. ${ }^{[9]}$

The main advantages of these transition metal based ILs are its easy preparation and the fact that they can be used as catalyst in green chemical protocols. Inspired on previous works by Powel and Dyson, ${ }^{[4 b, 10]}$ we have designed different IBLAILs changing $\mathrm{R}^{1}, \mathrm{R}^{2}$ and $\mathrm{R}^{3}$ groups (Figure 1 ), which have been analysed by ICP-MS ( $c a 15 \%$ of iron, see Supporting Information). The combination of the imidazolium chloride and iron(III) chloride in a $1: 1$ ratio provided the corresponding ionic liquid with the anion $\left[\mathrm{FeCl}_{4}\right]^{-}$, as described by different groups. ${ }^{[8,11]}$ Next, we studied the catalytic activity of these IBLAILs I-V in the allylic substitution reaction onto allylic alcohols. Herein, we report the results obtained from this study. 


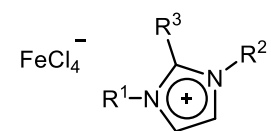

I : $\mathrm{R}^{1}=\mathrm{Me}, \mathrm{R}^{2}=\mathrm{CH}_{2} \mathrm{CO}_{2} \mathrm{Me}, \mathrm{R}^{3}=\mathrm{H}$

II $: \mathrm{R}^{1}=\mathrm{Me}, \mathrm{R}^{2}=\left(\mathrm{CH}_{2}\right)_{3} \mathrm{CO}_{2} \mathrm{Et}, \mathrm{R}^{3}=\mathrm{H}$

III : $\mathrm{R}^{1}=\mathrm{Me}, \mathrm{R}^{2}=\left(\mathrm{CH}_{2}\right)_{5} \mathrm{CO}_{2} \mathrm{Me}, \mathrm{R}^{3}=\mathrm{H}$

IV : $\mathrm{R}^{1}=\mathrm{Me}, \mathrm{R}^{2}=\left(\mathrm{CH}_{2}\right)_{3} \mathrm{CO}_{2} \mathrm{Et}, \mathrm{R}^{3}=\mathrm{Me}$

$\mathbf{V}: \mathrm{R}^{1}=\mathrm{n}-\mathrm{Bu}, \mathrm{R}^{2}=\mathrm{CH}_{2} \mathrm{CO}_{2} \mathrm{Me}, \mathrm{R}^{3}=\mathrm{H}$

VI : $\mathrm{R}^{1}=\mathrm{Me}, \mathrm{R}^{2}=\mathrm{CH}_{2} \mathrm{CO}_{2} \mathrm{H}, \mathrm{R}^{3}=\mathrm{H}$

Figure 1. Iron(III)-based Lewis acidic ionic liquids (IBLAILs).

\section{Results and Discussion}

\section{Catalytic activity of the iron(III) based Lewis} acidic imidazolium salts

The reaction between $(E)$-1,3-diphenylprop-2-en-1-ol (1a) and $N$-methylaniline (2a) was chosen as model reaction to optimize the reaction conditions (Scheme 1, Table 1). First, the reaction was carried out with 5 mol-\% of Fe(III)-based Lewis acidic ionic liquid I (Figure 1) at $25{ }^{\circ} \mathrm{C}$ under solvent free conditions. Unexpectedly, a 1:1 mixture of the para and ortho alkylation products (3aa and 4aa, respectively) was obtained, instead of the amination product, although the conversion was low (Table 1, entry 1). Previous protocols in the literature reveal that anilines as nucleophiles provide the corresponding $\mathrm{N}$ allylanilines as predominant product regardless of the catalyst employed (including iron(III) catalysts) and independently of the aniline derivative. ${ }^{[12]}$ In addition, the reaction between activated alcohols and aromatic compounds to produce C-alkylation products (Friedel-Crafts reaction) has been reported by means of different metal-based catalysts, ${ }^{[13]}$ albeit there are few examples for the formation of $\mathrm{C}$-alkylation products with anilines. ${ }^{[14]}$

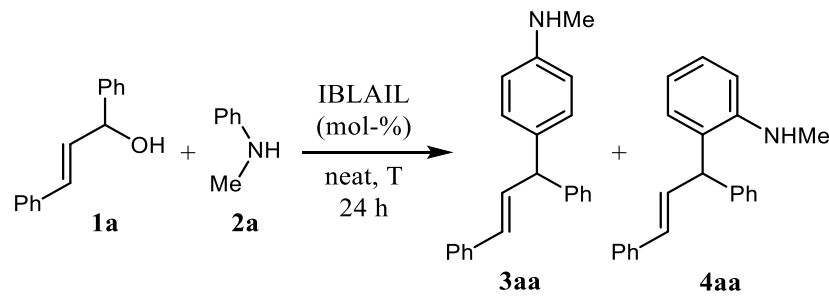

Scheme 1. Model reaction for the optimization of reaction conditions.

Rising the temperature to $50{ }^{\circ} \mathrm{C}$ and using IBLAIL I, the same mixture of products 3aa and 4aa was obtained in $32 \%$ and $34 \%$ of conversion respectively (Table 1 , entry 7). An increase on the catalyst loading to $10 \mathrm{~mol}-\%$ or on the temperature to $70^{\circ} \mathrm{C}$ did not produce a significant improvement in the results
(Table 1, entries 8, 10 and 11), albeit a slight selectivity towards compound 3aa was observed at 70 ${ }^{\circ} \mathrm{C}$. Next, we performed the reaction at $100{ }^{\circ} \mathrm{C}$, obtaining full conversion with $10 \mathrm{~mol}-\%$ of IBLAIL I, and $c a$. 3:1 selectivity ratio for the para-alkylated product 3aa (Table 1, entry 12). Other reaction conditions such as microwave irradiation at 50,70 or $100{ }^{\circ} \mathrm{C}$ were also tested, but lower conversions to the desired products were observed (Table 1, compare entries 13-16 with entries 9-12).

The properties of ionic liquids (such as imidazolium salts) vary depending on the size of the different components (i.e. cation and anion), ${ }^{[15]}$ so different substituents in the imidazole nitrogens can modulate the catalytic activity of the salts. Consequently, other Fe(III)-based Lewis acidic ionic liquids, such as II-VI (Figure 1), were evaluated as catalysts in the reaction between $1 \mathbf{a}$ and 2a. The reactions were performed with $10 \mathrm{~mol}-\%$ of IBLAIL (II-VI) at 25 and $70{ }^{\circ} \mathrm{C}$, in order to detect differences in the conversion and/or in the selectivity of the reaction. The use of IBLAILs II-VI provided comparable conversions and similar regioselectivities in our model reaction than catalyst IBLAIL I at $25^{\circ} \mathrm{C}$ (Table 1, entries 2-6), but different catalytic activity was observed in all cases at $70{ }^{\circ} \mathrm{C}$ (Table 1 , entries 11 , 17-19, 21 and 23). While catalysts II and III provided lower conversions than I at $70^{\circ} \mathrm{C}$ (Table 1, entries 17 and 18), catalysts IV, $\mathbf{V}$ and $\mathbf{V I}$ proved to be superior at that temperature (Table 1, entries 19, 21 and 23). Gratifyingly, when the reaction was performed at $100{ }^{\circ} \mathrm{C}$ for $24 \mathrm{~h}$ under solvent free conditions, using IBLAIL $\mathbf{V}$ as catalyst, $90 \%$ of conversion was obtained with complete regioselectivity towards the para-alkylation product 3aa (Table 1, entry 22). Salts IV and VI were also tested at $100{ }^{\circ} \mathrm{C}$ (Table 1 , entries 20 and 24), but the selectivity was lower than with V. Using IBLAIL V, the reaction was performed under microwave irradiation (Table 1, entries 25 and 26), but no improvement was observed. Furthermore, different solvents were evaluated, such as toluene, 1,2dichloroethane and dioxane (Table 1, entries 27-29), all providing, in general, lower conversions and regioselectivities than 'neat' reaction conditions (in the absence of solvent).

Table 1. Optimization of the reaction conditions ${ }^{\text {a) }}$

\begin{tabular}{ccccc}
\hline \multirow{2}{*}{ Entry } & \multirow{2}{*}{$\begin{array}{c}\text { IBLAIL } \\
(\text { mol-\% })\end{array}$} & T $\left({ }^{\circ} \mathrm{C}\right)$ & \multicolumn{2}{c}{ Conversion $(\%)^{\mathrm{b})}$} \\
\cline { 4 - 5 } & & 3aa & 4aa \\
\hline 1 & I (5) & 25 & 7 & 7 \\
2 & II (5) & 25 & 18 & 14 \\
3 & III (5) & 25 & 25 & 16 \\
4 & IV (5) & 25 & 30 & 16 \\
5 & V (5) & 25 & 15 & 11 \\
6 & VI (5) & 25 & 21 & 10 \\
7 & I (5) & 50 & 32 & 34 \\
8 & I (5) & 70 & 24 & 32 \\
9 & I (5) & 100 & 61 & 21 \\
10 & I (10) & 50 & 40 & 43 \\
11 & I (10) & 70 & 42 & 32
\end{tabular}




\begin{tabular}{|c|c|c|c|}
\hline 12 & I (10) & 100 & 73 \\
\hline $13^{\mathrm{c})}$ & I (10) & 50 & 9 \\
\hline $14^{\mathrm{c})}$ & I (10) & 70 & 40 \\
\hline $15^{\mathrm{c})}$ & I (10) & 100 & 37 \\
\hline $16^{\text {d) }}$ & I (10) & 100 & 28 \\
\hline 17 & II (10) & 70 & 18 \\
\hline 18 & III (10) & 70 & 35 \\
\hline 19 & IV (10) & 70 & 68 \\
\hline 20 & IV (10) & 100 & 84 \\
\hline 21 & $\mathbf{V}(10)$ & 70 & 63 \\
\hline 22 & $\mathbf{V}(10)$ & 100 & 90 \\
\hline 23 & VI (10) & 70 & 65 \\
\hline 24 & VI (10) & 100 & 75 \\
\hline $25^{\mathrm{c})}$ & $\mathbf{V}(10)$ & 70 & 22 \\
\hline $26^{c)}$ & $\mathbf{V}(10)$ & 100 & 47 \\
\hline $27^{\mathrm{e})}$ & $\mathbf{V}(10)$ & 100 & 25 \\
\hline $28^{\mathrm{f})}$ & $\mathbf{V}(10)$ & 100 & 36 \\
\hline $\left.29^{g}\right)$ & $\mathbf{V}(10)$ & 100 & 12 \\
\hline
\end{tabular}

a) Reaction conditions: 1a $(0.5 \mathrm{mmol}), 2 \mathrm{a}(0.5 \mathrm{mmol})$. Reaction performed in an open vessel. b) Conversion determined by GC analysis. ${ }^{c}$ Microwave irradiation was employed to heat the reaction. Microwaves conditions: 40 $\mathrm{W}$ (initial potency), $36 \mathrm{psi}$ and 60 minutes. ${ }^{\text {d) }}$ Microwave irradiation conditions: $40 \mathrm{~W}$ (initial potency), $36 \mathrm{psi}$ and 30 minutes. ${ }^{\text {e) }}$ Reaction performed with toluene $(0.2 \mathrm{~mL})$ as solvent. ${ }^{\text {f) }}$ Reaction performed with 1,2-dichloroethane (0.2 $\mathrm{mL})$ as solvent. ${ }^{\mathrm{g})}$ Reaction performed with dioxane $(0.2$ $\mathrm{mL}$ ) as solvent.

\section{Quinoline synthesis by allylic substitution and oxidative cyclization}

Next, we decided to explore para substituted anilines as nucleophiles. To our surprise, the reaction of $p$ toluidine (2b) with allylic alcohol $\mathbf{1 a}$ at $100{ }^{\circ} \mathrm{C}$ in the presence of $\mathbf{V}$ (10 mol- $\%)$ in the absence of solvent (Table 2) provided a mixture of the ortho alkylation product $\mathbf{4 a b}$ and the quinoline 5ab (Table 2, entry 1). The formation of the quinoline can be explained by an oxidative cyclization process ${ }^{[16]}$ after the allylic substitution reaction. In an attempt to improve the selectivity of the process and favor the quinoline formation, we evaluated different solvents (see Supporting Information) without any success. Only the use of 1,2-dichloroethane provided the corresponding ortho-alkylation product 4ab exclusively in $97 \%$ conversion (see Supporting Information). Working under 'neat' reaction conditions and extending the reaction time to $48 \mathrm{~h}$, the conversion to the desired quinoline 5ab increased to $62 \%$ (Table 2, entry 2). Raising the catalyst loading of IBLAIL $\mathbf{V}$ to 20 mol-\%, provided $92 \%$ of quinoline 5ab after $48 \mathrm{~h}$ (Table 2, entry 3). It is worth noting that in the absence of catalyst, no reaction was observed (Table 2, entry 4 and footnote d). When the imidazolium salt precursor of $\mathbf{V}$, without iron [i.e. 1(methoxy-carbonylmethyl)-3-butylimidazolium chloride] was tested as catalyst, only the ortho alkylation product 4ab with low conversion (20\%) was obtained after $48 \mathrm{~h}$ of heating at $100{ }^{\circ} \mathrm{C}$ (Table 2, entry 5). Furthermore, a mixture of both products $4 \mathbf{a b}$ and 5ab was obtained when 20 mol- $\%$ of $\mathrm{FeCl}_{3} \cdot 6 \mathrm{H}_{2} \mathrm{O}$ was used as catalyst under the same reaction conditions (Table 2, entry 6), although with very low conversion. Other ammonium tetrachloroferrate salts (i.e. benzyl(2-hydroxyethyl)dimethylammonium tetrachloroferrate and benzyl(triehtyl)ammonium tetrachloroferrate) in the absence of an imidazolium cation, were also tested in the reaction. These ammonium salts catalyzed the reaction between 1a and $\mathbf{2 b}$ with high conversion but giving a mixture of both compounds $\mathbf{4 a b}$ and $\mathbf{5 a b}$ (Table 2, entries 7 and 8 ). From these experiments, we concluded that the combination of iron(III) source with the imidazolium salt constitutes a better catalytic system in terms of activity and selectivity. IBLAIL $\mathbf{V}$ was highlighted as the optimal catalyst for the process, at a loading of 20 mol-\%. It is remarkable that the amount of iron(III) employed is about 3 mol-\% (20 mol-\% of $\mathbf{V}$, which contains $c a .15 \%$ of iron, measured by ICP).

Table 2. Optimization of reaction conditions for quinoline synthesis $^{\text {a) }}$

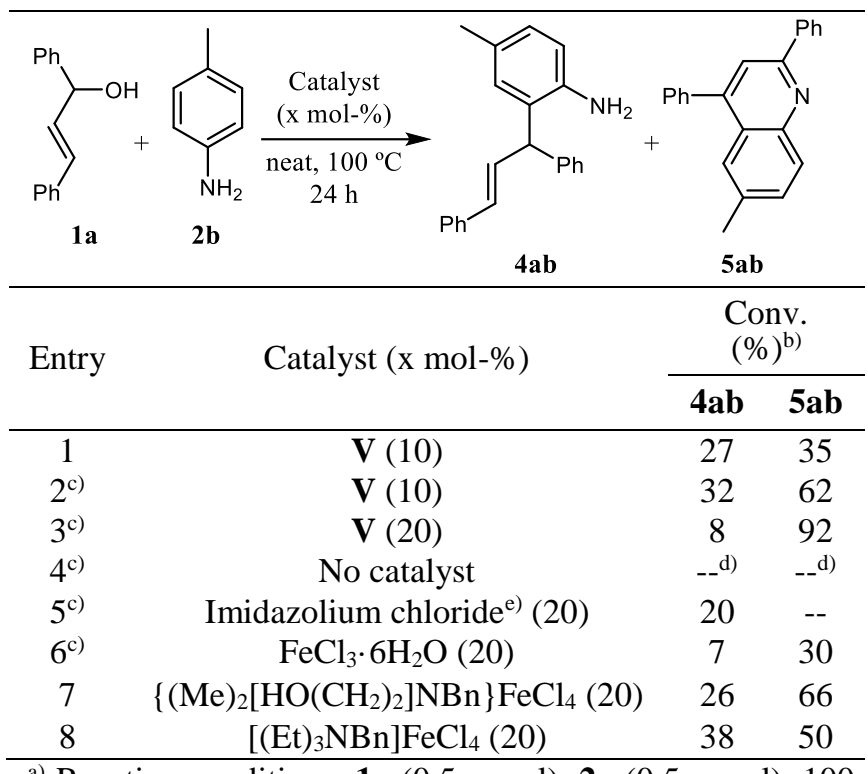

a) Reaction conditions: 1a $(0.5 \mathrm{mmol}), \mathbf{2 a}(0.5 \mathrm{mmol}), 100$ ${ }^{\circ} \mathrm{C}$. Reaction performed in an open vessel. b) Conversion was determined by GC analysis. ${ }^{\text {c) }}$ Reaction time: 48 h. ${ }^{\text {d) }}$ Less than $10 \%$ of the $N$-allylaniline was observed in the reaction crude together with the starting materials, but neither 4ab nor 5ab were observed. e) 1(Methoxycarbonylmethyl)-3-butylimidazolium chloride (20 mol-\%) was used as catalyst.

With the optimized reaction conditions for the preparation of quinolines in hand, we examined the scope of the present reaction with different anilines and allylic alcohol 1a (Table 3). As mentioned before, $p$-toluidine was transformed into the corresponding quinoline 5ab with excellent conversion (>90\%), being isolated in $70 \%$ yield. The electron rich substituted $p$-methoxy aniline provided quinoline 5ac in high yield (Table 3), however, the presence of two methoxy groups in the aniline caused lower yields (product 5ad, Table 3). Anilines provided with halogen groups, such as chloro and bromo, were also 
compatible with the present reaction conditions, affording the corresponding quinolines 5ae and 5af, respectively, in good yields (Table 3 ).

To broaden the scope to other allylic alcohols we carried out the reaction with cinnamyl alcohol (1b), (E)-4-phenylbut-3-en-2-ol (1c) and its isomeric allylic alcohol (E)-1-phenylbut-2-en-1-ol (1c'). Using $p$-toluidine (2b) as nucleophile, quinolines $\mathbf{5 b b}(76 \%$ from alcohol 1b) and 5cb (65\% from alcohol 1c and $60 \%$ from 1c') were obtained as exclusive regioisomers (Table 3 ). This fact can be explained by the stability of the double bond instead of the intermediate formed in the reaction media. ${ }^{[12]}$ Besides, (E)-3-(4-methoxyphenyl)-1-phenyl-prop-2-en-1-ol

(1d) produced a mixture of both possible regioisomers $\mathbf{5} \mathbf{d b}$ and $\mathbf{5} \mathbf{d b}$ ' (in a 2:1 ratio, Table 3), being, in this case, lower the difference in terms of stability between both intermediates.

Table 3. Quinoline synthesis: Scope ${ }^{\mathrm{a})}$

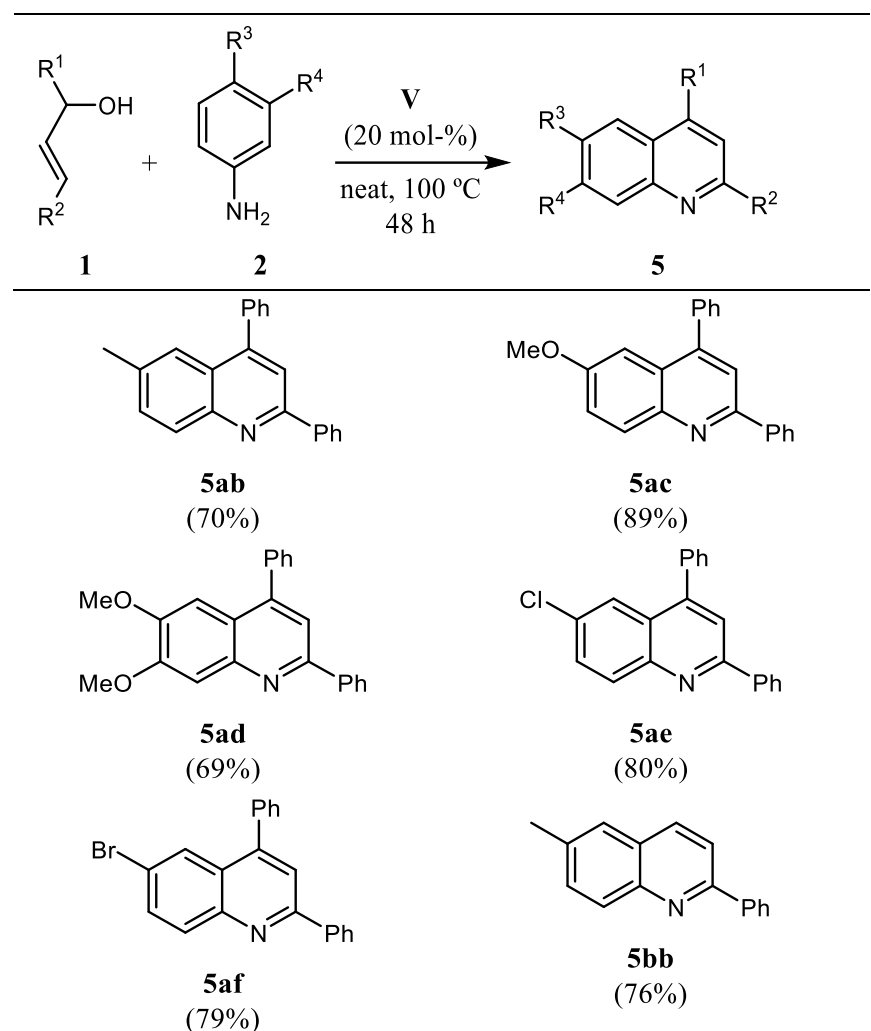<smiles>Cc1ccc2nc(-c3ccccc3)cc(C)c2c1</smiles>

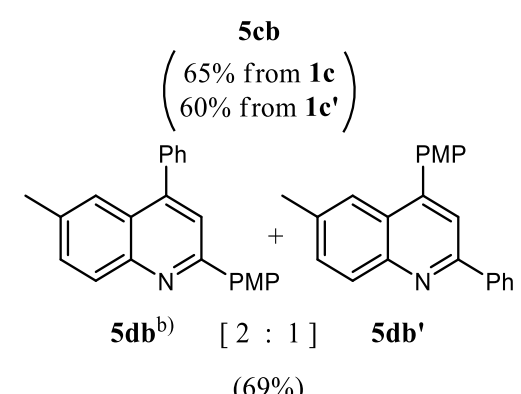

$(69 \%)$

a) Reaction conditions: 1a $(0.5 \mathrm{mmol}), 2$ (0.5 mmol), V (20 mol-\%), $100{ }^{\circ} \mathrm{C}$ for $48 \mathrm{~h}$. Reaction performed in an open vessel. In parentheses: Isolated yield after flash cromatography. ${ }^{\text {b) }} \mathrm{PMP}=$ para-methoxyphenyl.

\section{Mechanistic considerations in the formation of quinoline derivatives}

Several test were performed in order to get a better insight into the reaction mechanism for the formation of the quinoline derivatives. First, the reaction flask was flushed with a stream of air, to understand if the atmospheric oxygen was the oxidant agent. Indeed, both yield and conversion of the corresponding quinoline 5ab increased (full conversion and $79 \%$ isolated yield). On the contrary, only product 4ab was observed when the reaction was carried out under argon inert atmosphere (Scheme 2).

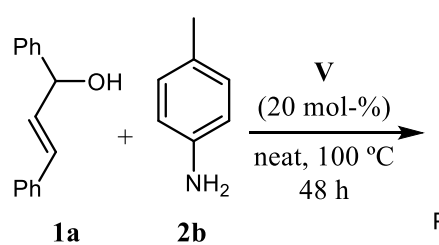

(a) Air stream (b) Argon atm.<smiles>Cc1ccc(N)c(C(/C=C/c2ccccc2)c2ccccc2)c1</smiles>

$90 \%$
$79 \%$
Scheme 2. Experiments under (a) air stream and (b) argon atmosphere. Isolated yields.<smiles>Cc1ccc(N)c(C(/C=C/c2ccccc2)c2ccccc2)c1</smiles>

$4 a b$

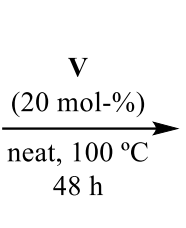

(a) Air atm.
(b) Argon atm<smiles>Cc1ccc(N)c(C(/C=C/c2ccccc2)c2ccccc2)c1</smiles>

$4 a b$

--

$90 \%$

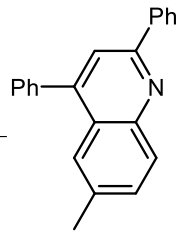

5ab

$99 \%$ $<5 \%$
Scheme 3. Experiments of oxidative cyclization under (a) air stream and (b) argon atmosphere. Isolated yields.

To reinsure that the atmospheric oxygen is the true oxidant in the process, the reaction, under inert atmosphere, was attempted on the ortho-alkylated product $\mathbf{4 a b}$. After 48 h, unaltered product $\mathbf{4 a b}$ was obtained as main product, together with a small amount of quinoline 5ab (less than 5\%, Scheme 3). In a parallel experiment, $4 \mathbf{a b}$ was treated with catalyst $\mathbf{V}$ under the optimized standard reaction conditions (air atmosphere), and quinoline 5ab was quantitatively obtained (Scheme 3). These experiments prove the importance of the atmospheric oxygen in our reaction. Consequently, it can be postulated that first the orthoalkylated intermediate $\mathbf{4 a b}$ is formed in the reaction media followed by an oxidative cyclization that leads to the formation of the corresponding quinoline. ${ }^{[16]}$ To corroborate this point, the product distribution 
profiles were obtained for the reaction between 1a and $\mathbf{2 b}$ (Figure 2), under the optimal reaction conditions (Table 2, entry 4). From this study, different conclusions can be drawn: (a) the corresponding product of ortho-alkylation (4ab) is formed in more than $90 \%$ in the first 5 minutes of the reaction (Figure 2); (b) this intermediate undergoes oxidative cyclization to form the corresponding quinoline during the rest of the reaction time (Figure 2). Moreover, the formation of the amination intermediate can be ruled out since it is not detected in the reaction profile.

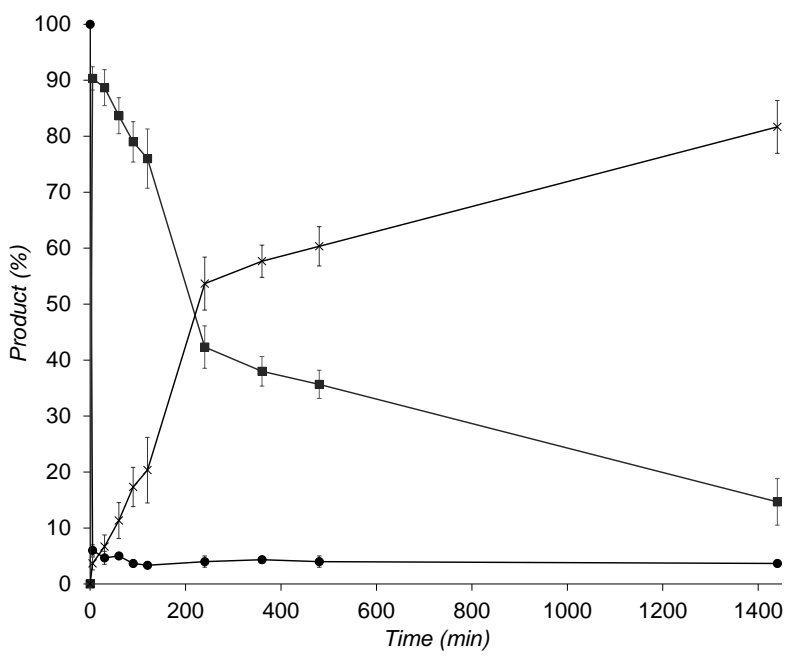

Figure 2. Product distribution profiles (by GC analysis) in the reaction media vs reaction time (minutes): (•) starting allylic alcohol 1a; ( $\mathbf{a})$ ortho-alkylation product $\mathbf{4 a b} ;(\mathbf{x})$ quinoline 5ab. Error bars represent standard deviation from three experiments.

Previous work by others, ${ }^{[12 b, 17]}$ demonstrates that allylic alcohol (E)-1,3-diphenylprop-2-en-1-ol (1a) could be oxidated to chalcone in the presence of $\mathrm{FeCl}_{3} \cdot 6 \mathrm{H}_{2} \mathrm{O}$ as catalyst at high temperatures. With this in mind, we decided to test whether this intermediate was involved with our catalytic system, the reaction going through a Doebner-Miller (or Skraup) synthesis. ${ }^{[18]}$ Thus, allylic alcohol 1a was stirred in the presence of IBLAIL $\mathbf{V}$ without aniline at $100{ }^{\circ} \mathrm{C}$, and after $48 \mathrm{~h}$, chalcone (6) was observed as the main product (Scheme 4). Next, the reaction of chalcone (6) with $p$-toluidine, under the optimized conditions, was attempted, however, only starting materials were recovered after $48 \mathrm{~h}$ (Scheme 4). Therefore, the formation of the imine intermediate can be discarded from our mechanistic pathway.

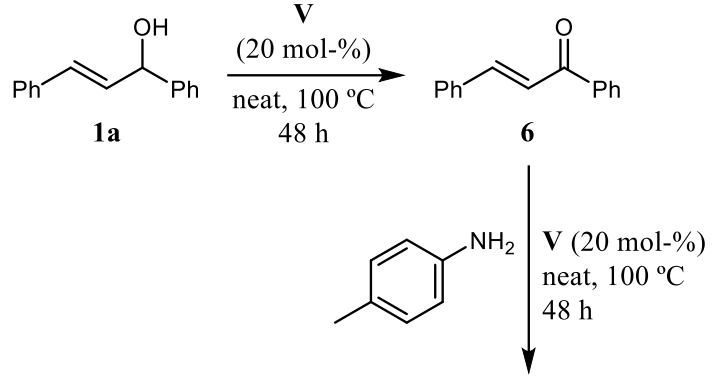

no reaction

Scheme 4. Oxidation of allylic alcohol to the chalcone under the optimized reaction conditions.

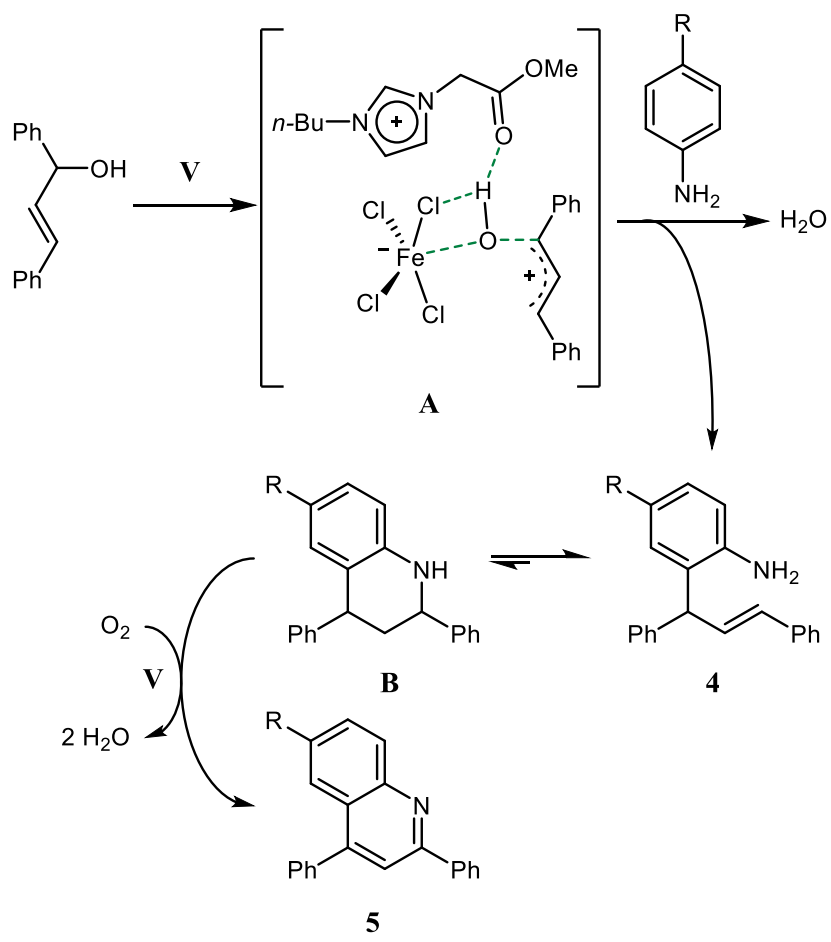

Scheme 5. Possible mechanism for the allylation and subsequent oxidation.

Based on these experiments and on similar transformations previously reported, ${ }^{[16]}$ we speculate that the mechanism for the formation of the corresponding quinolines involves an ortho-allylation process and a subsequent oxidation, as represented in Scheme 5. The iron(III) salt assists in the formation of an incipient allylic carbocation (intermediate A), ${ }^{[19]}$ which reacts with the aniline to produce the 2allylaniline derivative $\mathbf{4}$ and molecule of water via a Friedel-Crafts reaction. ${ }^{[13]}$ Compound $\mathbf{4}$ could be in equilibrium with the cyclized tetrahydroquinoline $\mathbf{B}$, although we believe this equilibrium must be shifted towards $\mathbf{4}$, since the tetrahydroquinoline $\mathbf{B}$ has never been observed. Next, the dehydrogenation with molecular oxygen (from air) promoted by iron generates quinoline $\mathbf{5}$ and two molecules of water (Scheme 5). ${ }^{[20]}$ The oxidation mediated by iron has been described before via a radical pathway. ${ }^{[21]} \mathrm{At}$ 
this point, a control experiment between $\mathbf{1 a}$ and $\mathbf{2 b}$ in the presence of a radical scavenger (i.e. cumene) ${ }^{[22]}$ under the standard conditions, was performed. After the reaction time $(48 \mathrm{~h})$, quinoline 5ab was only obtained in 9\%, whereas 2-allylaniline 4ab was produced in $89 \%$ conversion. Accordingly, it has been proved that the first step of the mechanism of the reaction is anionic (being the formation of 4ab not affected), but the second step (oxidation to 5ab) involves radicals (process that has been inhibited in the presence of the radical scavenger).

\section{ortho-Allylation of aniline derivatives}

Our optimization studies (vide supra) showed that milder reaction conditions favor the formation of ortho-alkylation products. For this reason, we decided to study the scope of the reaction between allylic alcohol 1a and different anilines, at $50{ }^{\circ} \mathrm{C}$ for 2 hours (Table 5). Under these conditions, the corresponding 2-allylanilines were selectively obtained in good to high yields, without detecting, in any case, the formation of the quinoline via oxidative cyclization. Thus, 4-substituted anilines with electron-donating groups, such as methyl, methoxy and phenoxy, provided the corresponding anilines 4ab, 4ac and 4ah, respectively in good yields (Table 4). Surprisingly and, to our delight, anilines with electron-withdrawing groups (e.g $\mathrm{Br}, \mathrm{Cl}$ ), which give no reaction or poor results with previously described catalytic systems, ${ }^{[14,23]}$ allowed the formation of products 4ae and 4af in high yield (Table 4). Furthermore, this methodology could be successfully extended to anilines bearing strong electronwithdrawing group (i.e. $\mathrm{NO}_{2}$ ), providing 4 aj in high yield (Table 4). Additionally, when the reaction was performed with 4-ethynylaniline, the product 4ai was obtained with good yield (Table 4) due to a triple bond hydration during the reaction.

Finally, a mixture of both 2-allyl and 4-allylaniline was obtained, when the $N$-methylaniline was employed as nucleophile. Compound 4aa was isolated in $43 \%$ yield under the reaction conditions detailed in Table 4, although the corresponding regioisomer 3aa was observed in 20\% yield. Similarly, the aniline nucleophile containing two methoxy groups at 2 and 5 positions gave a mixture of ortho and para-alkylation products with a preference for the ortho-alkylation product in a 2:1 ratio (compound 4ag in Table 4 and compound $\mathbf{3 a g}$ in Table 5).

\section{para-Allylation of aniline derivatives}

Last, we extended our study on the catalytic activity of IBLAIL $\mathbf{V}$ to anilines without para substituents. As far as we know, this class of substrates has been scarcely studied in protocols involving the synthesis of C-allylanilines. ${ }^{[14]}$ As detailed in Table 5, with our catalytic system, if the para and one or both ortho positions are available on the aniline ring, paraalkylation was preferentially observed instead of ortho-alkylation. In general, the corresponding 4allylanilines were obtained in good to excellent yields
(65-80\%) when performing the reaction at $100{ }^{\circ} \mathrm{C}$ as previously optimized (vide supra). Only the 2,5dimethoxy substituted aniline provided lower results (50\% yield).

Table 4. 2-Allylanilines synthesis: Scope ${ }^{\text {a) }}$

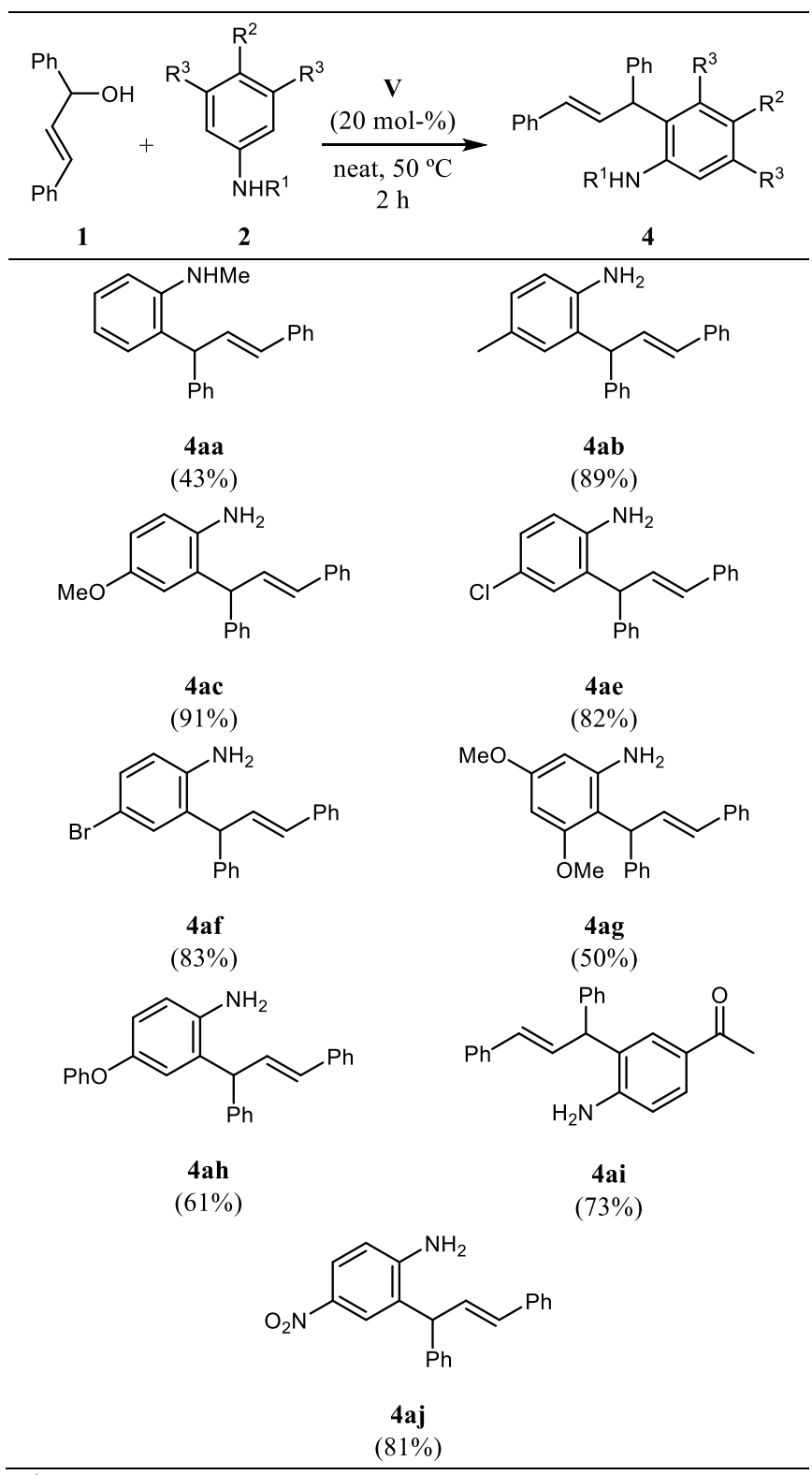

a) Reaction conditions: 1 (0.5 mmol), 2 (0.5 mmol), V (20 mol-\%), $50{ }^{\circ} \mathrm{C}$ for $2 \mathrm{~h}$. Reaction performed in an open vessel. In parentheses: Isolated yield after flash chromatography.

\section{Scale up and recycling}

The catalytic activity of IBLAIL $\mathbf{V}$ was also examined in bigger scale, under neat conditions. Thus, when the ortho-alkylation reaction between 1a and 2b was scaled up to $10 \mathrm{mmol}, 1.90$ grams of compound 4ab were obtained (64\% isolated yield, Scheme 6). 


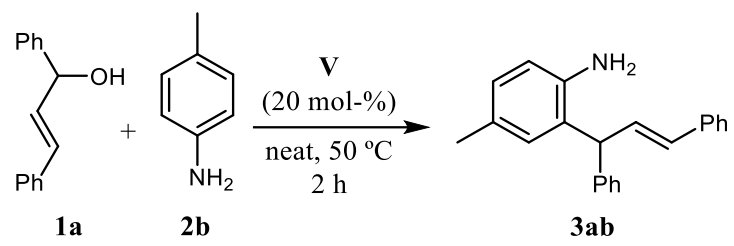

$64 \%$ yield, $1.90 \mathrm{~g}$

Scheme 6. Scaled up the 2-allylaniline 3ab synthesis.

Moreover, IBLAIL $\mathbf{V}$ could be recovered from the reaction mixture by simple washes with ethyl acetate and centrifugation of the reaction crude. The recovered IBLAIL $\mathbf{V}$ showed catalytic activity for the next three cycles, although a slight decrease in activity was observed (range $80-70 \%$ conversion, see Supporting Information). This fact maybe due to the reaction being carried out on a $10 \mathrm{mmol}$ scale.

Table 5. 4-Allylanilines synthesis: Scope ${ }^{\text {a) }}$

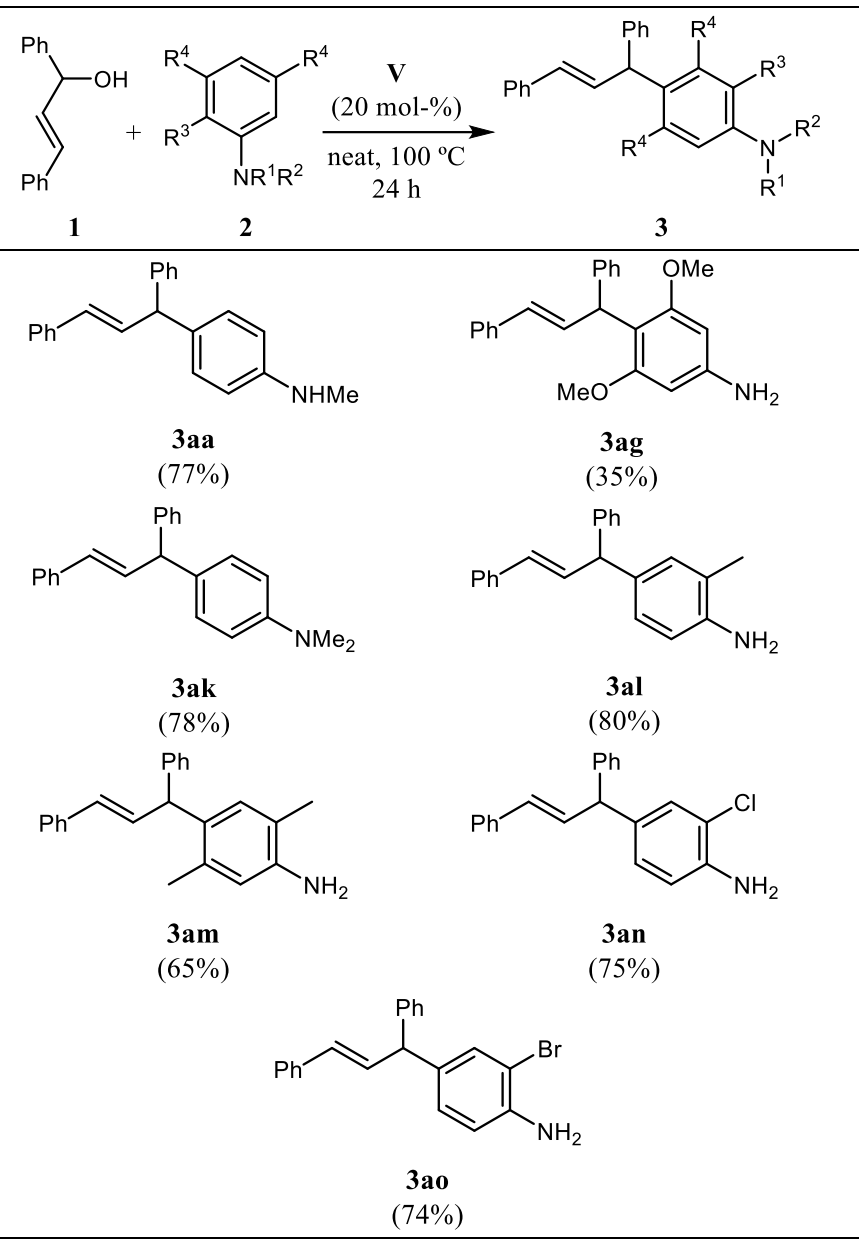

a) Reaction conditions: 1 (0.5 mmol), 2 (0.5 mmol), V (20 mol- $\%), 100{ }^{\circ} \mathrm{C}$ for $24 \mathrm{~h}$. Reaction performed in an open vessel. In parentheses: Isolated yield after flash chromatography.

\section{Conclusion}

To conclude, we have demonstrated the efficacy of $\mathrm{Fe}(\mathrm{III})$-based Lewis acidic ionic liquids, which are easy to prepare, as catalyst for the allylic substitution reaction of alcohols with anilines. In contrast with previously reported iron catalyzed procedures with allylic alcohol and anilines, IBLAIL catalysts did not promote $\mathrm{N}$-allylations, but $\mathrm{C}$-allylation reactions. C. $a$. 3 mol-\% of iron is employed in the different transformations, given that 20 mol- $\%$ of the IBLAIL is used as catalyst, which contains $c a .15 \%$ of iron.

The catalytic system proved versatile. Modulating the reaction conditions (temperature, reaction time), the catalytic system can be employed selectively in the preparation of quinoline derivatives, 2allylanilines and 4-allylanilines. The synthesis of quinolines, in a one pot reaction, involved an allylic substitution reaction in the ortho-position of the aniline and a subsequent oxidative cyclization promoted by atmospheric oxygen.

\section{Experimental Section}

\section{General}

All reagents and solvents were used as supplied commercially. Analytical thin-layer chromatography (TLC) was performed on $0.2 \mathrm{~mm}$ coated Science silica gel (EM 60-F254) plates purchased from Merck, Germany. Visualization was achieved by UV light $(254 \mathrm{~nm})$. Flash column chromatography was performed using silica gel and a gradient solvent system (hexane-ethyl acetate as eluent). ${ }^{1} \mathrm{H}$ and ${ }^{13} \mathrm{C}$ NMR spectra were measured on 300 and $400 \mathrm{MHz}$ spectrometers and the residual solvent peak was used as an internal reference: proton (chloroform $\delta$ $7.26 \mathrm{ppm}$ ) and carbon (chloroform $\delta 77 \mathrm{ppm}$ ). Chemical shifts (ppm) were recorded with tetramethylsilane (TMS) as the internal reference standard. Multiplicities are given as s (singlet), brs (broad singlet), d (doublet), t (triplet), dd (doublet of doublets) or $\mathrm{m}$ (multiplet). The number of protons (n) for a given resonance is indicated by $\mathrm{nH}$ and constant coupling are reported as a $J$ value in $\mathrm{Hz}$. The conversion of the reactions and purity of the products were determinate by $\mathrm{GC}$ analysis using a Younglin 6100GC, equipped with a flame ionization detector and a Phenomenex ZB-5MS column (5\% PH-ME siloxane): 30 $\mathrm{m}$ (length), $0.25 \mathrm{~mm}$ (inner diameter) and $0.25 \mu \mathrm{m}$ (film)

General procedure for the quinoline synthesis. To a $10 \mathrm{~mL}$ tube, IBLAIL (20 mol- $\%$ ), the corresponding allylic alcohol $(0.5 \mathrm{mmol})$ and aniline $(0.5 \mathrm{mmol})$ were sequentially added. The resultant reaction mixture was stirred at $100^{\circ} \mathrm{C}$ for $48 \mathrm{~h}$ in an open vessel. After this time. the reaction was diluted with ethyl acetate $(5 \mathrm{~mL})$ and washed with water $(3 \times 10 \mathrm{~mL})$. The organic extract was dried over anhydrous $\mathrm{MgSO}_{4}$. The solvent was removed under reduced pressure to provide the crude product, which was purified by flash column chromatography on silica gel using hexane-ethyl acetate as eluent.

6-Methyl-2,4-diphenylquinoline (5ab). ${ }^{[24]}$ Orange oil; ${ }^{1} \mathrm{H}$ NMR (300 MHz, $\left.\mathrm{CDCl}_{3}\right): \delta=8.18-8.13(\mathrm{~m}, 3 \mathrm{H}), 7.77(\mathrm{~s}$, $1 \mathrm{H}), 7.64(\mathrm{~s}, 1 \mathrm{H}), 7.56-7.22(\mathrm{~m}, 9 \mathrm{H}), 2.46(\mathrm{~s}, 3 \mathrm{H}) \mathrm{ppm} ;{ }^{13} \mathrm{C}$ NMR: $\delta=155.9,148.4,147.4,139.7,138.6,136.2,131,7$, $129.8,129.5,129.1,128.8,128.6,128.3,127.5,125.7$ $124.4,119.4,21.8 \mathrm{ppm}$; MS: $\mathrm{m} / \mathrm{z}(\%)=295(100)\left[\mathrm{M}^{+}\right]$, 294 (83), 281 (14), 280 (59), 189 (12), 140 (11), 139 (13).

6-Methoxy-2,4-diphenylquinoline (5ac). ${ }^{[25]}$ Brown oil; ${ }^{1} \mathrm{H}$ NMR $\left(300 \mathrm{MHz}, \mathrm{CDCl}_{3}\right): \delta=8.13-8.18(\mathrm{~m}, 3 \mathrm{H}), 7.78(\mathrm{~s}$, $1 \mathrm{H}), 7.26-7.58(\mathrm{~m}, 9 \mathrm{H}), 7.20(\mathrm{~d}, J=3 \mathrm{~Hz}, 2 \mathrm{H}), 3.81(\mathrm{~s}$ $3 \mathrm{H}), \mathrm{ppm} ;{ }^{13} \mathrm{C} \mathrm{NMR}\left(75 \mathrm{MHz}, \mathrm{CDCl}_{3}\right): \delta=131.6,129.3$, $128.9,128.8,128.7,128.3,127.3,126.3,121.8,119.7$, 103.7, 55.5, 29.7 ppm; MS: $\mathrm{m} / \mathrm{z}(\%)=311(100)\left[\mathrm{M}^{+}\right], 310$ (34), 296 (41), $267(10), 148$ (10). 
6,7-Dimethoxy-2,4-diphenylquinoline (5ad). ${ }^{[26]}$ Brown oil; ${ }^{1} \mathrm{H}$ NMR $\left(300 \mathrm{MHz}, \mathrm{CDCl}_{3}\right): \delta=8.14(\mathrm{~d}, J=8.1 \mathrm{~Hz}$, 2H), $7.67(\mathrm{~s}, 1 \mathrm{H}), 7.59-7.43(\mathrm{~m}, 8 \mathrm{H}), 7.17(\mathrm{~s}, 2 \mathrm{H}), 4.08(\mathrm{~s}$, $3 \mathrm{H}), 3.86(\mathrm{~s}, 3 \mathrm{H}) \mathrm{ppm} ;{ }^{13} \mathrm{C}$ NMR $\left(75 \mathrm{MHz}, \mathrm{CDCl}_{3}\right): \delta=$ $155.1,152.4,149.7,147.5,145.9,138.9,129.3,128.9$, $128.8,128.7,128.3,127.3,121.0,117.9,108.7,103.3,56.2$, $55.9 \mathrm{ppm} ; \mathrm{MS}: \mathrm{m} / \mathrm{z}(\%)=341(100)\left[\mathrm{M}^{+}\right], 340(11), 326$ (16), $311(33), 254$ (14).

6-Chloro-2,4-diphenylquinoline (5ae). ${ }^{[27]}$ Brown oil; ${ }^{1} \mathrm{H}$ NMR (400 MHz, $\left.\mathrm{CDCl}_{3}\right): \delta=7.21-7.34(\mathrm{~m}, 2 \mathrm{H}), 7.48-7.57$ $(\mathrm{m}, 6 \mathrm{H}), 7.67(\mathrm{dd}, J=2.2,8.9 \mathrm{~Hz}, 1 \mathrm{H}), 7.84(\mathrm{~s}, 1 \mathrm{H}), 7.86$ $(\mathrm{d}, \mathrm{J}=2.2 \mathrm{~Hz}, 1 \mathrm{H}), 8.16-8.19(\mathrm{~m}, 3 \mathrm{H}) \mathrm{ppm} ;{ }^{13} \mathrm{C}$ NMR $(100$ $\left.\mathrm{MHz}_{\mathrm{CDCl}}\right): \delta=120.1,124.5,126.3,126.5,127.5,128.7$, $128.8,128.9,129.4,129.6,130.4,131.7,132.2,137.7$, 139.2, 147.2, 148.5, 157.1 ppm; MS: $\mathrm{m} / \mathrm{z}(\%)=315(92)$ $\left[\mathrm{M}^{+}\right], 314$ (100), 280 (30), 278 (16), 201 (13), 176 (11), $140(17), 139(20)$.

6-Bromo-2,4-diphenylquinoline (5af). ${ }^{[28]}$ Yellow oil; ${ }^{1} \mathrm{H}$ NMR $\left(300 \mathrm{MHz}, \mathrm{CDCl}_{3}\right): \delta=7.49-7.57(\mathrm{~m}, 8 \mathrm{H}), 7.79(\mathrm{~d}, J$ $=8.9 \mathrm{~Hz}, 1 \mathrm{H}), 7.83(\mathrm{~s}, 1 \mathrm{H}), 8.09(\mathrm{~s}, 1 \mathrm{H}), 8.12(\mathrm{~s}, 1 \mathrm{H})$, $8.16-8.20(\mathrm{~m}, 2 \mathrm{H}) \mathrm{ppm} ;{ }^{13} \mathrm{C}$ NMR $\left(75 \mathrm{MHz}, \mathrm{CDCl}_{3}\right): \delta=$ $119.4,120.1,127.6,127.6,127.8,128.6,128.7,128.9$, 129.4, 129.6, 131.9, 133.0, 137.8, 139.1, 147.6, 148.3, $157.2 \mathrm{ppm} ; \mathrm{MS}: \mathrm{m} / \mathrm{z}(\%)=359(100)\left[\mathrm{M}^{+}\right], 358(85), 282$ (10), 281 (17), 280 (59), 279 (16), 278 (38), 277 (15), 203 (12), 202 (22), 201 (20), 176 (18), 139 (39), 138 (35).

6-Methyl-2-phenylquinoline (5bb). ${ }^{[29]}$ Brown oil; ${ }^{1} \mathrm{H}$ NMR (300 MHz, $\left.\mathrm{CDCl}_{3}\right): \delta=8.16-8.12(\mathrm{~m}, 3 \mathrm{H}), 8.07$ (d, $J$ $=8.5 \mathrm{~Hz}, 1 \mathrm{H}), 7.84(\mathrm{~d}, J=8.6 \mathrm{~Hz}, 1 \mathrm{H}), 7.63-7.38(\mathrm{~m}, 5 \mathrm{H})$, $2.55(\mathrm{~s}, 3 \mathrm{H}) \mathrm{ppm} ;{ }^{13} \mathrm{C} \mathrm{NMR}\left(75 \mathrm{MHz}, \mathrm{CDCl}_{3}\right): \delta=156.5$, $146.9,139.8,136.1,129.4,129.1,128.8,127.5,127.127 .2$, 126.3, 118.9, $21.6 \mathrm{ppm} ; \mathrm{MS}: \mathrm{m} / \mathrm{z}(\%)=220(17)\left[\mathrm{M}^{+}+1\right]$, 219 (100) $\left[\mathrm{M}^{+}\right], 218$ (47), 217 (12), 204 (15), 109 (11).

4,6-dimethyl-2-phenylquinoline (5cb). ${ }^{[30]}{ }^{1} \mathrm{H}$ NMR $(300$ $\left.\mathrm{MHz}, \mathrm{CDCl}_{3}\right): \delta=2.57$ (s, 3H), $2.74(\mathrm{~s}, 3 \mathrm{H}), 7.14(\mathrm{~s}, 1 \mathrm{H})$, 7.41-7.59 (m, 5H), 7.68-7.85 (m, 2H), 8.05-8.16 (m, 1H) ppm; ${ }^{13} \mathrm{C}$ NMR $\left(75 \mathrm{MHz}, \mathrm{CDCl}_{3}\right): \delta=140.0,136.1,135.9$, $131.9,131.5,129.9,128.8,128.3,127.4,126.3,122.6$, $119.8,118.9,21.9,19.0 \mathrm{ppm} ; \mathrm{MS}: \mathrm{m} / \mathrm{z}(\%)=233(100)$ $\left[\mathrm{M}^{+}\right], 232(27), 218(41), 217$ (12).

2-(4-Methoxyphenyl)-6-methyl-4-phenylquinoline (5db) and 4-(4-Methoxyphenyl)-6-methyl-2-phenylquinoline (5db'). ${ }^{[31]}{ }^{1} \mathrm{H}$ NMR (300 MHz, $\left.\mathrm{CDCl}_{3}\right): \delta=8.18-8.08(\mathrm{~m}$, $6 \mathrm{H}), 7.75(\mathrm{~s}, 1 \mathrm{H}), 7.73(\mathrm{~s}, 1 \mathrm{H}), 7.62(\mathrm{~s}, 1 \mathrm{H}), 7.56-7.49(\mathrm{~m}$, $14 \mathrm{H}), 7.09(\mathrm{~d}, J=8.8 \mathrm{~Hz}, 1 \mathrm{H}), 7.09(\mathrm{~d}, J=8.9 \mathrm{~Hz}, 2 \mathrm{H})$, $3.92(\mathrm{~s}, 3 \mathrm{H}), 3.88(\mathrm{~s}, 3 \mathrm{H}), 2.48(\mathrm{~s}, 3 \mathrm{H}), \mathbf{2 . 4 6}(\mathrm{s}, 3 \mathrm{H}) \mathrm{ppm}$; ${ }^{13} \mathrm{C}$ NMR $\left(75 \mathrm{MHz}, \mathrm{CDCl}_{3}\right): \delta=160.7,155.6,148.3,147.4$, $138.8,136.1,135.8,132.4,131.6,130.9,130.8,129.9$, $129.6,129.5,129.1,128.8,128.5,128.2,127.5,126.3$, $125.4,124.4,124.3,119.4,118.9,114.2,114.1,113.9,55.4$, 55.38, 21.8, 21.77 ppm. MS (5db): $\mathrm{m} / \mathrm{z}(\%)=325(100)$ $\left[\mathrm{M}^{+}\right], 324$ (46), 310 (30), 281 (12). MS (5db'): $\mathrm{m} / \mathrm{z}(\%)=$ $325(100)\left[\mathrm{M}^{+}\right], 324(43), 311$ (14), 310 (46), 294 (21), 281 (19), 280 (12), 267 (14), 207 (14).

\section{General procedure for the 2-allylanilines synthesis.}

To a $10 \mathrm{~mL}$ tube were successively added IBLAIL (20 mol-\%), allylic alcohols $(0.5 \mathrm{mmol})$ and aniline $(0.5 \mathrm{mmol})$. The resultant reaction mixture was stirred at $50{ }^{\circ} \mathrm{C}$ for 2 hours. After this time, the reaction was diluted with ethyl acetate $(5 \mathrm{~mL})$ and washed with water $(3 \times 10 \mathrm{~mL})$. The organic extract was dried over anhydrous $\mathrm{MgSO}_{4}$. The solvent was removed under reduced pressure to provide the crude product which was purified by flash column chromatography on silica gel using hexane-ethyl acetate as eluent.

(E)-2-(1,3-Diphenylallyl)- $N$-methylaniline (4aa). Amber oil: FT-IR (neat): 3058, 3024, 2921, 2814, 1601, 1509 , $1491,1459,1448,1377,1307,1263,1222,1158 \mathrm{~cm}^{-1} ;{ }^{1} \mathrm{H}$
$\operatorname{NMR}\left(300 \mathrm{MHz}, \mathrm{CDCl}_{3}\right): \delta=7.38-7.17(\mathrm{~m}, 11 \mathrm{H}), 7.07(\mathrm{dd}$, $J=7.6,1.4 \mathrm{~Hz}, 1 \mathrm{H}), 6.75(\mathrm{td}, J=7.5,1.1 \mathrm{~Hz}, 1 \mathrm{H}), 6.76-$ $6.69(\mathrm{~m}, 2 \mathrm{H}), 6.24(\mathrm{dd}, J=15.9,1.1 \mathrm{~Hz}, 1 \mathrm{H}), 4.84(\mathrm{~d}, J=$ $6.8 \mathrm{~Hz}, 1 \mathrm{H}), 2.74(\mathrm{~s}, 3 \mathrm{H}) \mathrm{ppm} ;{ }^{13} \mathrm{C} \mathrm{NMR}(75 \mathrm{MHz}$ $\left.\mathrm{CDCl}_{3}\right): \delta=146.7,141.8,137.1,131.7,131.4,128.9,128.8$, $128.5,127.8,127.6,127.3,127.1,126.8,126.3,117.1$, $110.5,49.2,30.8 \mathrm{ppm} ; \mathrm{MS}: \mathrm{m} / \mathrm{z}(\%)=299(12)\left[\mathrm{M}^{+}\right], 209$ (17), 208 (100), 206 (16), 194 (13), 193 (23); HRMS (ESI): Calcd. for $\mathrm{C}_{22} \mathrm{H}_{21} \mathrm{~N}$ (M+): 299.1674, found 299.1664.

(E)-2-(1,3-Diphenylallyl)-4-methylaniline

$(4 \mathbf{a b}) \cdot{ }^{[14]}$ Orange oil; ${ }^{1} \mathrm{H}$ NMR $\left(400 \mathrm{MHz}, \mathrm{CDCl}_{3}\right): \delta=7.38-7.21(\mathrm{~m}$, $10 \mathrm{H}), 6.90(\mathrm{~s}, 1 \mathrm{H}), 6.68(\mathrm{dd}, J=15.9,7.1 \mathrm{~Hz}, 1 \mathrm{H}), 6.60(\mathrm{~d}$ $J=8.5 \mathrm{HZ}, 1 \mathrm{H}), 6.28(\mathrm{~d}, J=15.9 \mathrm{HZ}, 1 \mathrm{H}), 4.87(\mathrm{~d}, J=7.1$ $\mathrm{Hz}, 1 \mathrm{H}), 3.41$ (brs, 2H), $2.23(\mathrm{~s}, 3 \mathrm{H}) \mathrm{ppm} ;{ }^{13} \mathrm{C}$ NMR $(100$ $\left.\mathrm{MHz}, \mathrm{CDCl}_{3}\right): \delta=141.9,141.7,137.2,131.6,131.5,129.7$, $128.8,128.7,128.5,128.1,127.3,126.7,126.4,116.7$, 49.62, 29.7 ppm; MS: m/z (\%) = $299(27)\left[\mathrm{M}^{+}\right], 209(18)$ 208 (100), 207 (36), 206 (11), 194 (12), 193 (19), 191 (11).

(E)-4-Methoxy-2-(1,3-diphenylallyl)aniline

(4ac). ${ }^{[14]}$ Brown oil; ${ }^{1} \mathrm{H}$ NMR $\left.\left(300 \mathrm{MHz}^{\mathrm{CDCl}}\right)_{3}\right): \delta=7.38-7.21(\mathrm{~m}$, $10 \mathrm{H}), 6.71-6.62(\mathrm{~m}, 4 \mathrm{H}), 6.30(\mathrm{~d}, J=15.9 \mathrm{~Hz}, 1 \mathrm{H}), 4.90(\mathrm{~d}$, $J=6.9 \mathrm{~Hz}, 1 \mathrm{H}), 3.71(\mathrm{~s}, 3 \mathrm{H}), 3.30(\mathrm{~s}, 2 \mathrm{H}) \mathrm{ppm} ;{ }^{13} \mathrm{C} \mathrm{NMR}$ $\left(75 \mathrm{MHz} \mathrm{CDCl}_{3}\right): \delta=152.9,141.6,137.9,131.6,131.1$, $128.8,128.7,128.5,127.9,127.4,126.8,126.5,117.5$, 115.8, 112.1,55.6, 49.6 ppm; MS: $\mathrm{m} / \mathrm{z}(\%)=315(69)\left[\mathrm{M}^{+}\right]$, 225 (18), 224 (100), 223 (28), 210 (14), 209 (23), 207 (12), 193 (12), 191 (14), 180 (12), 178 (10), 167 (14), 165 (11), $115(13), 91$ (18).

(E)-4-Chloro-2-(1,3-diphenylallyl)aniline

(4ae).$^{[12 \mathrm{c}]}$ Orange oil; ${ }^{1} \mathrm{H}$ NMR $\left(300 \mathrm{MHz}, \mathrm{CDCl}_{3}\right): \delta=7.40-7.18(\mathrm{~m}$, $9 \mathrm{H}), 7.1(\mathrm{~d}, J=8.9 \mathrm{~Hz}, 2 \mathrm{H}) 6.60-6.49(\mathrm{~m}, 3 \mathrm{H}), 6.34$ (dd, $J$ $=15.9,6.1 \mathrm{~Hz}, 1 \mathrm{H}), 5.01(\mathrm{~d}, J=6.1 \mathrm{~Hz}, 1 \mathrm{H}), 4.10(\mathrm{brs}, 2 \mathrm{H})$ ppm:13 $\mathrm{C}$ NMR $\left(75 \mathrm{MHz}, \mathrm{CDCl}_{3}\right): \delta=145.7,141.6,136.4$, $131.3,130.2,128.9,128.8,128.7,128.5,127.8,127.6$, $127.1,126.5,122.3,114.7,60.7$ ppm; MS: m/z $(\%)=319$ (5) $\left[\mathrm{M}^{+}\right], 194$ (21), 193 (100), 192 (12), 191 (13), 178 (19), 127 (23), 115 (59), 91 (16).

(E)-4-Bromo-2-(1,3-diphenylallyl)aniline

(4af). ${ }^{[16]}$

Yellow oil; ${ }^{1} \mathrm{H}$ NMR $\left(300 \mathrm{MHz}, \mathrm{CDCl}_{3}\right): \delta=7.17-7.34(\mathrm{~m}$, $12 \mathrm{H}), 6.59(\mathrm{dd}, J=15.9,7.0 \mathrm{~Hz}, 1 \mathrm{H}), 6.52(\mathrm{~d}, J=8.95 \mathrm{~Hz}$, $1 \mathrm{H}), 6.26(\mathrm{dd}, J=15.9,1.1 \mathrm{~Hz}, 1 \mathrm{H}), 4.80(\mathrm{~d}, J=6.8 \mathrm{~Hz}$, 1H), 3.51 (brs, $2 \mathrm{H}) \mathrm{ppm} ;{ }^{13} \mathrm{C}$ NMR (75 MHz, $\mathrm{CDCl}_{3}$ ): $\delta=$ $143.3,140.9,136.8,132.1,131.9,131.7,130.3,130.3$ $130.1,128.9,128.7,128.5,127.6,127.1,126.4,117.9$ 116.6, 110.7, $49.5 \mathrm{ppm} ; \mathrm{MS}: \mathrm{m} / \mathrm{z}(\%)=363(18)\left[\mathrm{M}^{+}\right], 284$ (22), 274 (28), 273 (42), 272 (29), 271 (39), 206 (26), 193 (100), 191 (21), $165(15), 102$ (12), 91 (18).

(E)-2-(1,3-Diphenylallyl)-3,5-dimethoxyaniline (4ag) Pale yellow oil; FT-IR (neat): 3371, 3023, 2934, 2837 , $1597,1491,1448,1202,1153,1120,1078 \mathrm{~cm}^{-1} ;{ }^{1} \mathrm{H}$ NMR $\left(300 \mathrm{MHz}, \mathrm{CDCl}_{3}\right): \delta=7.39(\mathrm{dd}, J=8.3 \mathrm{~Hz}, 1.2 \mathrm{~Hz}, 1 \mathrm{H})$ $7.09-7.32(\mathrm{~m}, 8 \mathrm{H}), 6.94(\mathrm{dd}, J=15.9,8.5 \mathrm{~Hz}, 1 \mathrm{H}), 6.48(\mathrm{~d}$, $J=15.8 \mathrm{~Hz}, 1 \mathrm{H}), 5.92(\mathrm{~s}, 2 \mathrm{H}), 5.39(\mathrm{~d}, J=8.5 \mathrm{~Hz}, 1 \mathrm{H})$, $3.66(\mathrm{~s}, 6 \mathrm{H}) \mathrm{ppm}$; $13 \mathrm{C} \mathrm{NMR}(75 \mathrm{MHz}, \mathrm{CDCl} 3): \delta=158.9$, $146.5,144.9,128.2,132.4,130.2,128.3,127.6,127.4$ 126.6, 126.2, 125.1, 110.6, 92.5, 55.7, 42.9, ppm; MS: m/z $(\%)=345(100)[\mathrm{M}+], 315(26), 314(87), 268(19), 254$ (20), 239 (15), 207 (11), 167 (11), 166 (82), 164 (11), 153 (27), 152 (13), 124 (12), 115 (16), 91 (19); HRMS (ESI): Calcd for $\mathrm{C}_{23} \mathrm{H}_{23} \mathrm{NO}_{2}(\mathrm{M}+)$ : 345.1729 , found 345.1722 .

(E)-2-(1,3-Diphenylallyl)-4-phenoxyaniline

(4ah). ${ }^{[14]}$ Brown oil; ${ }^{1} \mathrm{H}$ NMR $\left(300 \mathrm{MHz}, \mathrm{CDCl}_{3}\right): \delta=7.35-722(\mathrm{~m}$, $11 \mathrm{H}), 7.02-6.89(\mathrm{~m}, 5 \mathrm{H}), 6.79(\mathrm{dd}, J=8.5,2.74 \mathrm{~Hz}, 1 \mathrm{H})$ $6.67(\mathrm{~d}, J=8.5 \mathrm{~Hz}, 1 \mathrm{H}), 6.62(\mathrm{dd}, J=15.9,7.0 \mathrm{~Hz}, 1 \mathrm{H})$, 6.29 (dd, $J=15.9,1.1 \mathrm{~Hz}, 1 \mathrm{H}), 4.88(\mathrm{~d}, J=7.0 \mathrm{~Hz}, 1 \mathrm{H})$ 3.47 (brs, 2H) ppm; ${ }^{13} \mathrm{C} \mathrm{NMR}\left(75 \mathrm{MHz}, \mathrm{CDCl}_{3}\right): \delta=158.8$, $148.6,141.3,140.5,136.9,131.8,130.9,129.9,129.5$, $128.8,128.7,128.5,127.5,127.3,126.9,126.4,121.9$ $121.3,119.1,117.4,117.1,49.6 \mathrm{ppm} ; \mathrm{MS}: \mathrm{m} / \mathrm{z}(\%)=370$ (31) $\left[\mathrm{M}^{+}-77\right], 299$ (100), 207 (12). 
(E)-1-(4-Amino-3-(1,3-diphenylallyl)phenyl)ethanone (4ai). Orange oil; FT-IR (neat): 3349, 3058, 3027, 1654, $1591,1522,1491,1449,1420,1357,1271,1177 \mathrm{~cm}^{-1} ;{ }^{1} \mathrm{H}$ NMR $\left(300 \mathrm{MHz}, \mathrm{CDCl}_{3}\right): \delta=7.78(\mathrm{~d}, J=8.8 \mathrm{~Hz}, 2 \mathrm{H})$, 7.19-7.48 (m, 9H), 6.57-6.62 (m, 3H), 6.37 (dd, $J=15.9$, $6.0 \mathrm{~Hz}, 1 \mathrm{H}), 5.18(\mathrm{t}, J=5.4 \mathrm{~Hz}, 1 \mathrm{H}), 4.70$ (brs, $2 \mathrm{H}), 2.46$ (s, 3H) ppm; $\left.{ }^{13} \mathrm{C} \mathrm{NMR} \mathrm{(75} \mathrm{MHz,} \mathrm{CDCl}_{3}\right): \delta=196.3,150.9$ $131.7,130.6,129.4,128.9,128.6,127.8,127.1,126.5$, $112.4,59.9,25.9$, ppm; MS: $\mathrm{m} / \mathrm{z}(\%)=327(5)\left[\mathrm{M}^{+}\right], 207$ (12), 194 (21), 193 (100), 178 (20), 135 (20), 120 (37), 115 (52), 92 (19), 91 (16); HRMS (ESI): Calcd for $\mathrm{C}_{23} \mathrm{H}_{21} \mathrm{NO}$ (M+): 327.1623 , found 327.1616.

(E)-2-(1,3-Diphenylallyl)-4-nitroaniline (4aj). ${ }^{[16]}$ Yellow solid; m.p.: $128.3{ }^{\circ} \mathrm{C} ;{ }^{1} \mathrm{H}$ NMR $\left(300 \mathrm{MHz}, \mathrm{CDCl}_{3}\right): \delta=$ $8.02(\mathrm{~d}, J=9.2 \mathrm{~Hz}, 2 \mathrm{H}), 7.13-7.51(\mathrm{~m}, 9 \mathrm{H}), 6.50-6.66(\mathrm{~m}$, $3 \mathrm{H}), 6.36(\mathrm{dd}, J=15.9,6.1 \mathrm{~Hz}, 1 \mathrm{H}), 5.19(\mathrm{t}, J=4.8 \mathrm{~Hz}$, $1 \mathrm{H}), 4.99(\mathrm{~d}, J=4.1 \mathrm{~Hz}, 2 \mathrm{H}) \mathrm{ppm} ;{ }^{13} \mathrm{C}$ NMR $(75 \mathrm{MHz}$, $\left.\mathrm{CDCl}_{3}\right): \delta=152.1,140.2,132.2,129.1,128.6,128.5,128.1$, $127.1,126.5,126.2,112.1,59.9$, ppm; MS: $\mathrm{m} / \mathrm{z}(\%)=330$ (2) $\left[\mathrm{M}^{+}\right], 194$ (27), 193 (100), 178 (19), 116 (11), 115 (18), $108(11), 91(13)$.

General procedure for the ortho-alkylation products. To a $10 \mathrm{~mL}$ tube were successively added IBLAIL (20 mol-\%), allylic alcohols $(0.5 \mathrm{mmol})$ and aniline $(0.5 \mathrm{mmol})$. The resultant reaction mixture was stirred at $100^{\circ} \mathrm{C}$ for 24 hours. After this time, the reaction was diluted with ethyl acetate $(5 \mathrm{~mL})$ and washed with water $(3 \times 10 \mathrm{~mL})$. The organic extract was dried over anhydrous $\mathrm{MgSO}_{4}$. The solvent was removed under reduced pressure to provide the crude product which was purified by flash column chromatography on silica gel using hexane-ethyl acetate as eluent.

(E)-4-(1,3-Diphenylallyl)-N-methylaniline (3aa). Amber oil; FT-IR (neat): 3058, 3024, 2929, 2881, 1613, 1491, $1448,1317,1265,1183 \mathrm{~cm}^{-1} ;{ }^{1} \mathrm{H}$ NMR $\left(400 \mathrm{MHz}, \mathrm{CDCl}_{3}\right)$ : $\delta=7.36(\mathrm{~d}, J=8.2 \mathrm{~Hz}, 2 \mathrm{H}), 7.33-7.15(\mathrm{~m}, 8 \mathrm{H}), 7.05(\mathrm{~d}, J$ $=8.3 \mathrm{~Hz}, 2 \mathrm{H}), 6.65(\mathrm{dd}, J=15.8,7.5 \mathrm{~Hz}, 1 \mathrm{H}), 6.57(\mathrm{~d}, J=$ $8.3 \mathrm{~Hz}, 2 \mathrm{H}), 6.32(\mathrm{~d}, J=15.8 \mathrm{~Hz}, 1 \mathrm{H}), 4.79(\mathrm{~d}, J=7.5 \mathrm{~Hz}$, $1 \mathrm{H}), 2.82(\mathrm{~s}, 3 \mathrm{H}) \mathrm{ppm} ;{ }^{13} \mathrm{C} \mathrm{NMR}\left(75 \mathrm{MHz}, \mathrm{CDCl}_{3}\right): \delta=$ $147.8,144.2,137.4,133.3,132.0,130.7,129.3,128.7$, $128.6,128.4,128.3,127.0,126.2,126.1,112.4,53.3,30.7$ ppm; MS: m/z (\%) = 299 (100) $\left[\mathrm{M}^{+}\right], 298$ (50), 222 (17), 191 (14), 165 (12), 120 (19); HRMS (ESI): Calcd. for $\mathrm{C}_{22} \mathrm{H}_{21} \mathrm{~N}\left(\mathrm{M}^{+}\right): 299.1674$, found 299.1666

(E)-4-(1,3-Diphenylallyl)-3,5-dimethoxyaniline (3ag). Yellow solid; m.p.: $144.2{ }^{\circ}$ C; FT-IR (neat): 3420,3341 , $3058,3025,2936,2835,1607,1594,1491,1466,1449$, $1428,1238,1216,1203,1153,1090 \mathrm{~cm}^{-1} ;{ }^{1} \mathrm{H}$ NMR $(300$ $\left.\mathrm{MHz}, \mathrm{CDCl}_{3}\right): \delta=7.14-7.43(\mathrm{~m}, 10 \mathrm{H}), 6.84(\mathrm{dd}, J=15.9$, $7.5 \mathrm{~Hz}, 1 \mathrm{H}), 6.47(\mathrm{dd}, J=15.9,1 \mathrm{~Hz}, 1 \mathrm{H}), 6.02(\mathrm{~d}, J=2.4$ $\mathrm{Hz}, 1 \mathrm{H}), 5.82(\mathrm{~d}, J=2.4 \mathrm{~Hz}, 1 \mathrm{H}), 5.54(\mathrm{~d}, J=7.4 \mathrm{~Hz}, 1 \mathrm{H})$, $3.74(\mathrm{~s}, 3 \mathrm{H}), 3.72(\mathrm{~s}, 3 \mathrm{H}) \mathrm{ppm} ;{ }^{13} \mathrm{C}$ NMR $(75 \mathrm{MHz}$, $\left.\mathrm{CDCl}_{3}\right): \delta=159.8,159.1,146.4,142.7,137.5,131.5,128.5$, 128.4, 128.38, 128.3, 127.6, 127.5, 127.0, 126.2, 126.1, $108.3,94.4,89.7,55.8,54.9,42.5 \mathrm{ppm} ; \mathrm{MS}: \mathrm{m} / \mathrm{z}(\%)=$ 345 (70) $\left[\mathrm{M}^{+}\right], 315$ (14), 314 (54), 255 (17), 254 (100), 253 (46), 240 (15), 239 (15), 224 (10), 223 (13), 192 (18), 191 (28), 178 (13), 167 (11), 166 (28), 165 (10), 153 (15), 115 (14), 91 (15); HRMS (ESI): Calcd. for $\mathrm{C}_{23} \mathrm{H}_{23} \mathrm{NO}_{2}\left(\mathrm{M}^{+}\right)$: 345.1729 , found 345.1730 .

(E)-4-(1,3-Diphenylallyl)- $N, N$-dimethylaniline (3ak). ${ }^{[32]}$ Red oil; ${ }^{1} \mathrm{H}$ NMR $\left(300 \mathrm{MHz}, \mathrm{CDCl}_{3}\right): \delta=7.38-7.19(\mathrm{~m}$, $10 \mathrm{H}), 7,10(\mathrm{~d}, J=8.6 \mathrm{~Hz}, 2 \mathrm{H}), 6.72-6.62(\mathrm{~m}, 3 \mathrm{H}), 6.33(\mathrm{~d}$, $J=15.9 \mathrm{~Hz}, 1 \mathrm{H}), 4.81(\mathrm{~d}, J=7.6 \mathrm{~Hz}, 1 \mathrm{H}), 2.92(\mathrm{~s}, 6 \mathrm{H})$ ppm; $\left.{ }^{13} \mathrm{C} \mathrm{NMR} \mathrm{(75} \mathrm{MHz,} \mathrm{CDCl}_{3}\right): \delta=149.2,144.2,136.3$, $133.3,130.8,129.2,128.6,128.4,128.3,127.6,127.1$, $126.3,126.2,112.8,53.3,40.8 \mathrm{ppm} ; \mathrm{MS}: \mathrm{m} / \mathrm{z}(\%)=313$ (100) $\left[\mathrm{M}^{+}\right], 312$ (44), $236(21), 210$ (10), 191 (22), 165 (18), $134(21), 117$ (11).

(E)-4-(1,3-Diphenylallyl)-2-methylaniline (3al). ${ }^{[14]}$ Pale yellow oil; ${ }^{1} \mathrm{H}$ NMR $\left(300 \mathrm{MHz}, \mathrm{CDCl}_{3}\right): \delta=7.38-7.19(\mathrm{~m}$, $10 \mathrm{H}), 6.91(\mathrm{~s}, 1 \mathrm{H}), 6.88(\mathrm{~s}, 1 \mathrm{H}), 6.65(\mathrm{dd}, J=15.4,7.5 \mathrm{~Hz}$,
$1 \mathrm{H}), 6.32(\mathrm{~d}, J=15.4 \mathrm{~Hz}, 1 \mathrm{H}), 4.77(\mathrm{~d}, J=7.5 \mathrm{~Hz}, 1 \mathrm{H})$, $3.59(\mathrm{~s}, 2 \mathrm{H}), 2.08(\mathrm{~s}, 3 \mathrm{H}) \mathrm{ppm} ;{ }^{13} \mathrm{C} \mathrm{NMR}(75 \mathrm{MHz}$, $\left.\mathrm{CDCl}_{3}\right): \delta=144.1,142.9,137.4,133.6,133.3,130.8,130.7$ $128.6,128.4,128.3,127.1,127.0,126.3,126.2,122.4$ $115.0,53.4,17.5 \mathrm{ppm} ; \mathrm{MS}: \mathrm{m} / \mathrm{z}(\%)=299(100)\left[\mathrm{M}^{+}\right], 298$ (31), 285 (15), 284 (64), 222 (17), 208 (12), 207 (14), 206 (19), 193 (14), 192 (14), 191 (23), 180 (16), 165 (11), 120 (24), 115 (15).

(E)-4-(1,3-Diphenylallyl)-2,5-dimethylaniline (3am). Orange oil; FT-IR (neat): $3023,2923,2854,1624,1598$, 1572, 1491, 1461, 1447, 1290, 1204, $1028 \mathrm{~cm}^{-1} ;{ }^{1} \mathrm{H}$ NMR $\left(300 \mathrm{MHz}, \mathrm{CDCl}_{3}\right): \delta=7.39-7.12(\mathrm{~m}, 10 \mathrm{H}), 6.83(\mathrm{~s}, 1 \mathrm{H})$, $6.64(\mathrm{dd}, J=15.9,6.9 \mathrm{~Hz}, 1 \mathrm{H}), 6.50(\mathrm{~s}, 1 \mathrm{H}), 6.19(\mathrm{~d}, J=$ $15.9,1 \mathrm{H}), 4.95(\mathrm{~d}, J=6.9 \mathrm{~Hz}, 1 \mathrm{H}), 3.49$ (brs, $2 \mathrm{H}), 2.16(\mathrm{~s}$, $3 \mathrm{H}), 2.09$ (s, 3H) ppm; ${ }^{13} \mathrm{C}$ NMR $\left(75 \mathrm{MHz}, \mathrm{CDCl}_{3}\right): \delta=$ $143.5,142.8,137.6,134.8,133.3,131.6,130.7,130.6$, $128.8,128.4,128.2,127.1,126.3,126.0,119.8,117.3,49.8$ 19.32, $17.0 \mathrm{ppm} ; \mathrm{MS}: \mathrm{m} / \mathrm{z}(\%)=313(92)\left[\mathrm{M}^{+}\right], 298(100)$, 236 (15), 221 (13), 220 (16), 207 (13), 206 (14), 193 (12), 192 (11), 191 (25), 165 (10), 134 (33), 115 (14), 91 (11) HRMS (ESI): Calcd. for $\mathrm{C}_{23} \mathrm{H}_{23} \mathrm{~N}\left(\mathrm{M}^{+}\right) 313.1833$, found 313.1826

(E)-2-Chloro-6-(1,3-diphenylallyl)aniline

(3an). ${ }^{[14]}$ Yellow oil; ${ }^{1} \mathrm{H}$ NMR $\left(300 \mathrm{MHz}, \mathrm{CDCl}_{3}\right): \delta=7.38-7.20(\mathrm{~m}$ $10 \mathrm{H}), 7.11(\mathrm{~d}, J=2.0 \mathrm{~Hz}, 1 \mathrm{H}), 6.92(\mathrm{dd}, J=8.2,2.0 \mathrm{~Hz}$, $1 \mathrm{H}), 6.71(\mathrm{~d}, J=8.2 \mathrm{~Hz}, 1 \mathrm{H}), 6.60(\mathrm{dd}, J=15.8,7.4 \mathrm{~Hz}$, $1 \mathrm{H}) 6.32(\mathrm{~d}, J=15.8 \mathrm{~Hz}, 1 \mathrm{H}), 4.76(\mathrm{~d}, J=7.4 \mathrm{~Hz}, 1 \mathrm{H})$ 3.97 (brs, $2 \mathrm{H}) \mathrm{ppm} ;{ }^{13} \mathrm{C} \mathrm{NMR}\left(75 \mathrm{MHz}, \mathrm{CDCl}_{3}\right): \delta=143.4$, $141.3,137.2,134.5,132.4,131.4,129.3,128.6,128.5$, $128.4,127.9,127.3,126.5,126.3,119.3,115.9 \mathrm{ppm} ; \mathrm{MS}$ $\mathrm{m} / \mathrm{z}(\%)=319(100)\left[\mathrm{M}^{+}\right], 318(26), 284(61), 242(15)$ 241 (14), 206 (41), $193(28), 192$ (31), 191 (31), 180 (25), 178 (15), 165 (15), 152 (13), 140 (23), 115 (19), 91 (14).

(E)-2-bromo-6-(1,3-diphenylallyl)aniline

(3ao) ${ }^{[14]}$ Yellow oil; ${ }^{1} \mathrm{H}$ NMR $\left(300 \mathrm{MHz}, \mathrm{CDCl}_{3}\right): \delta=7.38-7.20(\mathrm{~m}$ $10 \mathrm{H}), 6.98-6.97(\mathrm{~m}, 1 \mathrm{H}), 6.70(\mathrm{~d}, J=8.2 \mathrm{~Hz}, 1 \mathrm{H}), 6.59(\mathrm{dd}$, $J=15.8,7.4 \mathrm{~Hz}, 1 \mathrm{H}), 6.32(\mathrm{~d}, J=15.8 \mathrm{~Hz}, 1 \mathrm{H}), 4.76(\mathrm{~d}, J$ $=7.4 \mathrm{~Hz}, 1 \mathrm{H}), 4.01$ (brs, 2H) ppm; ${ }^{13} \mathrm{C}$ NMR $(75 \mathrm{MHz}$, $\left.\mathrm{CDCl}_{3}\right): \delta=143.4,142.5,137.2,134.8,132.4,132.4,131.4$, $128.7,128.54,128.5,128.4,127.5,127.3,126.5,126.3$, $115.8,109.4,53.0,29.7 \mathrm{ppm} ; \mathrm{MS}: \mathrm{m} / \mathrm{z}(\%)=365$ (99) $\left[\mathrm{M}^{+}\right], 364$ (46), 363 (99), 362 (25), 285 (28), 284 (100), 283 (21), 208 (20), 207 (66), 206 (86), 204 (16), 193 (42), 192 (45), 191 (49), 185 (21), 180 (44), 178 (25), 165 (30), 152 (25), 103 (30), 91 (24), 78 (13).

\section{Acknowledgements}

This work was financially supported by the University of Alicante.

\section{References}

[1] a) P. T. Anastas, J. C. Warner, Green Chemistry: Theory and Practice, Oxford University Press: New York, 1998; b) R. A. Sheldon, I. Arends, U. Hanefeld, Green Chemisty and Catalysis, Wiley-VCH: Weinheim, 2007.

[2] For selected reviews about allylic substitution reactions with free allylic alcohols, see: a) J. Muzart, Eur. J. Org. Chem. 2007, 3077-3089; b) M. Bandini, M. Tragni, Org. Biomol. Chem. 2009, 7, 1501-1507; c) E. Emer, R. Sinisi, M. G. Capdevila, D. Petruzziello, F. De Vicentiis, P. G. Cozzi, Eur. J. Org. Chem. 2011, 647666; d) M. Bandini, Angew. Chem. 2011, 123, 10261027; Angew. Chem. Int. Ed. 2011, 50, 994-995; e) B. Biannic, A. Aponick, Eur. J. Org. Chem. 2011, 66056617; f) B. Sundaraju, M. Achard, C. Bruneau, Chem. 
Soc. Rev. 2012, 41, 4467-4483; g) A. Baeza, C. Nájera Synthesis 2014, 46, 25-34.

[3] I. Bauer, H.-J. Knölker, Chem. Rev. 2015, 115, 31703387.

[4] a) O. E. Zhuravlev, N. V. Verolainen, L. I. Voronchikhina, Russ. J. Appl. Chem. 2011, 84, 11581164 ; b) D. Prodius, F. Macaev, E. Stingaci, V. Pogrebnoi, V. Mereacre, G. Novitchi, G. E. Kostakis, C. E. Anson, A. K. Powell, Chem. Commun. 2013, 49, 1915-1917; c) M. R. dos Santos, A. F. Gomes, F. C. Gozzo, P. A. Z. Suarez, B. A. D. Neto, ChemSusChem 2012, 5, 2383-2389; d) Z. Guo, T. Zhang, T. Liu, J. Du, B. Jia, S. Gao, J. Yu, Environ. Sci. Technol. 2015, 49, 5697-5703; e) T. S. Rodrigues, F. Machado, P. M. Lalli, M. N. Eberlin, B. A. D. Neto, Catal. Commun. 2015, 63, 66-73; f) O. Nacham, K. D. Clark, J. L. Anderson, RSC Adv. 2016, 6, 11109-11117; g) T. Tian, X. Hu, P. Guan, Y. Tang, J. Chem. Eng. Data 2016, 61, 721-730.

[5]N. H. Ko, J. S. Lee, E. S. Huh, H. Lee, K. D. Jung, H. S. Kim, M. Cheong, Energ. Fuel. 2008, 22, 1687-1690.

[6] H. Li, W. Zhu, Y. Wang, J. Zhang, J. Lu, Y. Yan, Green Chem. 2009, 11, 810-815.

[7] K. Bica, P. Gaertner, Org. Lett. 2006, 8, 733-735.

[8]M. D. Nguyen, L. V. Nguyen, E. H. Jeon, J. H. Kim, M. Cheong, H. S. Kim, J. S. Lee, J. Catal. 2008, 258, 5-13.

[9]L. M. Ramos, B. C. Guido, C. C. Nobrega, J. R. Corrêa, R. G. Silva, H. C. B. de Oliveira, A. F. Gomes, F. C. Gozzo, B. A. D. Neto, Chem. Eur. J. 2013, 19, 41564168.

[10] Z. Fei, D. Zhao, T. J. Geldbach, R. Scopelliti, P. J. Dyson, Chem. Eur. J. 2004, 10, 4886-4893.

[11] J.-G. Li, Y.-F. Hu, S.-F. Sun, S. Ling, J.-Z. Zhang J. Phys. Chem. B 2012, 116, 6461-6464.

[12] a) P. Trillo, A. Baeza, C. Nájera, Eur. J. Org. Chem. 2012, 2929-2934; b) P. Trillo, A. Baeza, C. Nájera, ChemCatChem 2013, 5, 1538-1542; c) P. Trillo, A. Baeza, C. Nájera, J. Org. Chem. 2012, 77, 7344-7354.

[13] a) M. Rueping, B. J. Nachtsheim, Beilstein J. Org. Chem. 2010, 6, doi:10.3762/bjoc.6.6; b) I. Fernández, D. Schott, S. Gruber, P. S. Pregosin, Helv. Chim. Acta 2007, 90, 271-276; c) I. Fernández, R. Hermatschweiler, F. Breher, P. S. Pregosin, L. F. Veiros, M. J. Calhorda, Angew. Chem. 2006, 118, 6535-6540; Angew. Chem. Int. Ed. 2006, 45, 6386-6391; d) B. Das, A. Maijhi, J. Banerjee, N. Chowdhury, K. Venkateswarly, Chem. Lett. 2005, 34, 1492-1493; e) G. Onodera, H. Imajima, M. Yamanashi, Y. Nishibayashi, M. Hidai, S. Uemura, Organometallics 2004, 23, 5841-5848.; f) J. Wang, L. Zhang, Y. Jing, W. Huang, X. Zhou, Tetrahedron Lett. 2009, 50, 4978-4982.

[14] Recent synthesis of ortho-allylanilines, see: a) K. Chen, Y. Li, S. Pullarkat, P.-H. Leung, Adv. Synth. Catal. 2012, 354, 83-87; b) K. Chen, H. J. Chen, J. Wong, J. Yang, S. Pullarkat, ChemCatChem. 2013, 5, 3882-3888; c) R. Nallagonda, M. Rehan, P. Ghorai, J. Org. Chem. 2014, 79, 2934-2943.
[15] a) P. Wasserscheid, W. Keim, Angew. Chem. 2000, 112, 3926-3945; Angew. Chem. Int. Ed. 2000, 39; 3772-3789; b) C. Bidart, R. Jiménez, C. Carlesi, M. Flores, Á. Berg, Chem. Eng. J. 2011, 175, 388-395.

[16] For recent oxidative cycloisomerization of orthocinnamylanilines, see: a) M. Rehan, G. Hazra, P. Ghorai, Org. Lett. 2014, 16, 4786-4789; b) M. Rehan, G. Hazra, P. Ghorai, Org. Lett. 2015, 17, 1668-1671.

[17] J. Wang, W. Huang, Z. Zhang, X. Xiang, R. Liu, X. Zhou, J. Org. Chem. 2009, 74, 3299-3304.

[18] a) R. H. F. Manske, M. Kulka, Org. React. 1953, 7 , 59-72; b) E. W. Cohn, J. Am. Chem. Soc. 1930, 52, 3685-3688; c) W. W. Kouznetsov, L. Y. V. Mendez, C. M. M. Gomez, Curr. Org. Chem. 2005, 9, 141-161; d) S. A. Yamashkin, E. A. Oreshkina, Chem. Heterocyc. Compd. 2006, 42, 701-719; e) J. Marco-Contelles, E. Pérez-Mayoral, A. Samidi, M. C. Carreiras, E. Soriano, Chem. Rev. 2009, 109, 2652-2671.

[19] a) U. Jana, S. Biswas, S. Maiti, Eur. J. Org. Chem. 2008, 5798-5804; b) P. Thirupathi, S. S. Kim, Tetrahedron 2010, 66, 2995-3003; c) A. N. Kazakova, R. O. Iakovenko, I. A. Boyarskaya, V. G. Nenajdenko, A. V. Vasilyev, J. Org. Chem. 2015, 80, 9506-9517.

[20] a) K. Cao, F.-M. Zhang, Y.-Q. Tu, X.-T. Zhuo, C.-A. Fan, Chem. Eur. J. 2009, 15, 6332-6334; b) Z.-G. Wang, Y.-G. Xia, Y. Jin, M. Lu, J. Chin. Chem. Soc. 2015, 62, 103-106; c) M. P. Singh, S. Sasmal, W. Lu, M. N. Chatterjee, Synthesis 2000, 1380-1390; d) H. Eshghi, M. Rahimizadeh, A. Shir, P. Sedaghat, Bull. Korean Chem. Soc. 2012, 33, 515-518.

[21] a) X. Chen, T. Chen, F. Ji, Y. Zhou, S.-F. Yin, Catal. Sci. Technol. 2015, 5, 2197-2202; b) C. J. Evoniuk, S. P. Hill, K. Hanson, I. V. Alabugin, Chem. Commun. 2016, 52, 7138-7141; c) M. R. dos Santos, J. R. Diniz, A. M. Arouca, A. F. Gomes, F. C. Gozzo, S. M. Tamborim, A. L Parize, P. A. Z. Suarez, B. A. D. Neto, ChemSusChem 2012, 5, 716-726.

[22] F. Alonso, A. Arroyo, I. Martín-García, Y. Moglie, Adv. Synth. Catal. 2015, 357, 3549-3561.

[23] K. Motokura, N. Nakagiri, T. Mizugaki, K. Ebitani, K. Kaneda, J. Org. Chem. 2007, 72, 6006-6015.

[24] R. P. Korivi, C-H. Cheng, J. Org. Chem. 2006, 71, 7079-7082.

[25] X. Li, M. Zhenjun, W. Yanguang, C. Weixiang, L. Xufeng, Tetrahedron 2011, 67, 3858-3862.

[26] M. Prabhuswamy, S. Madan Kumar, T. R. Swaroop, K. S. Rangappa, N. K. Lokanath, Acta Cryst. 2014, E70, 0165.

[27] Y. Wang, C. Chen, J. Peng, M. Li, Angew. Chem. 2013, 125, 5431-5435; Angew. Chem. Int. Ed. 2013, 52, 5323-5327.

[28] C. Yao, B. Qin, H. Zhang, J. Lu, D. Wang, S. Tu, RSC Adv. 2012, 2, 3759-3764.

[29] T. Demande, L. Knerr, P. Pasau, J. Comb. Chem. 2004, 4, 768-775. 
[30] J. M. Urbina, J. C. G. Cortés, A. Palma, S. N. López, S. A. Zachino, R. D. Enriz, J. C. Ribas, V. V. Kouznetzov, Bioorg. Med. Chem. 2000, 8, 691-698.

[31] a) R. Deshidi, S. Devari, B. Ali Shah, Org. Chem. Front. 2015, 2, 515-519; b) J. Liu, F. Liu, Y. Zhu, X. Ma, X. Jia, Org. Lett. 2015, 17, 1409-1412.
[32] Y. Tao, B. Wang, J. Zhao, Y. Song, L. Qu, J. Qu, J Org. Chem. 2012, 77, 2942-2946. 


\section{FULL PAPER}

Iron-based imidazolium salts as versatile catalysts in the synthesis of quinolines, 2- and 4-allylanilines by allylic substitution of alcohols

Adv. Synth. Catal.Year, Volume, Page - Page

Paz Trillo* and Isidro M. Pastor*

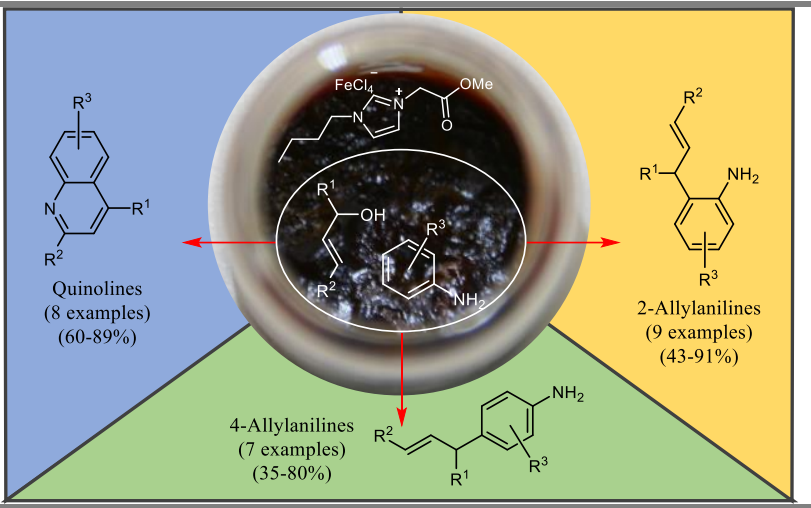

